\title{
THE EVOLUTION OF SMALL CLAIMS COURT: RISING MONETARY LIMITS AND USE OF LEGAL REPRESENTATION
}

\author{
Shelley McGill*
}

Do higher small claims court monetary limits expand access to "simplified" justice or do they erode the character of the "People's Court"? This paper reports the initial findings of a study of claims filed in the Toronto Small Claims Court in the two years before and after Ontario raised the Court's monetary limit from \$10,000 to \$25,000. Claim values and distribution across the value range are significantly changed following the monetary limit increase while claim volume remains at pre-increase levels. Predictably, proportionate use of legal representation by plaintiffs and defendants also increases after the limit increase.

Les limites pécuniaires plus élevées qui s'appliquent à la compétence de la Cour des petites créances ont-elles pour effet d'élargir l'accès à la justice "simplifiée " ou plutôt d'affaiblir le caractère populaire de cette " cour du peuple »? Ce document fait état des premiers résultats d'une étude des réclamations déposées à la Cour des petites créances de Toronto au cours des deux années qui ont précédé et suivi la date à laquelle l'Ontario a fait passer la limite pécuniaire de la compétence de la Cour de $10000 \$$ à $25000 \$$. Les valeurs des réclamations et leur répartition dans la fourchette de valeurs évoluent sensiblement après l'augmentation des limites pécuniaires, tandis que le volume des réclamations demeure semblable à celui qu'il était avant cette hausse. L'utilisation proportionnelle de représentants juridiques par les demandeurs et les défendeurs augmente également après l'accroissement des limites, ce qui était prévisible.

\section{INTRODUCTION}

Does increasing the maximum monetary limit for Small Claims Court claims expand access to quick, easy, informal dispute resolution ${ }^{1}$ or does it compromise the core tenets underlying civil access to justice and erode the character of the People's Court? These are the questions at the heart of an empirical study of claims filed in the Toronto Small Claims Court between 2008 and 2012. Effective January $1^{\text {st }} 2010$, Ontario raised its Small Claims Court monetary limit from $\$ 10,000$ to $\$ 25,000 ;^{2}$ the largest one time

\footnotetext{
* Associate Professor, Business Law, Wilfrid Laurier University, Deputy Judge, Ontario Small Claims Court, Central South; The author is grateful for funding from the Social Sciences and Humanities Research Council of Canada (SSHRC) and also for the cooperation of the Ministry of the Attorney General, Court Services Division and the Toronto Small Claims Court staff. The author would also like to recognize the outstanding work done by research assistants Brandon Mattalo BBA (WLU), JD (Queens) and Luke Sinclair, BBA (WLU), JD (UWO). Finally, the author appreciates the helpful comments provided by her WLU colleagues Dr. Sapna Isotupa and Dr. Christine Neill.

1 Seana C McGuire \& Roderick A Macdonald, "Small Claims Court Cant” (1996) 34:3 Osgoode Hall LJ 509 at 511, n 3 [McGuire \& Macdonald (1996)].

2 O Reg 439/08. All values are expressed in Canadian dollars [Ontario Small Claims Reg].
} 
increase in the Court's over 200 year history, ${ }^{3}$ and the third increase in the previous 10 years. ${ }^{4}$ This study, funded by the Social Sciences and Humanities Research Council of Canada, examines the impact of the increase on disputant behaviour, resolution process and claim characteristics.

Familiar criticisms typically waged against monetary limit increases in Small Claims Court are that higher limits attract more commercial and business claims and that the higher "stakes" attract more lawyers; both of which complicate the process and undermine its "People's Court" character. ${ }^{5}$ To investigate the validity of these criticisms, data about claims filed during the 2 years prior to and following the limit increase was retrieved from government files and examined to identify differences (if any) in the resolution of disputes filed during the two time periods. In this, the first in a series of papers describing the findings of the study, the impact of the monetary limit increase on claim volume, claim value, and use of representation is examined.

Interestingly, the analysis of claim volume data finds that the court was not overwhelmed with new cases after the limit increase; actual volume of claims filed showed only a temporary modest increase before falling to below pre-increase levels. However, claim value is a different story; comparison of sample data collected from before and after the limit increase reveals statistically significant changes in claim values and distribution across the respective monetary limits: fewer claims spread over a wider monetary jurisdiction after the limit increase. Most importantly, with respect to representation, the data reveals an increase in use of independent representation after the limit increase, a significant shift towards lawyers and paralegals.

This paper describes the study's context, scope, limitations and first findings in eight parts. Following this Introduction, the sparse existing empirical research related to Small Claims Court access to justice is reviewed in Part II. Next, Part III describes the Toronto Small Claims Court and provides an overview of Ontario Small Claims Court civil procedure. Part IV outlines the methodology followed in the

3 Ontario Small Claims Court dates back to 1792 when it debuted in a stand alone form as the Court of Requests introduced as a place where small business to efficiently collect its outstanding debts: Statutes of Upper Canada 1792 (32 Geo III) c 6, s 1 (UC); see James H Aitchison, "The Court of Requests in Upper Canada" (1949) 41 Ontario History 125 at 125-32. See generally Margaret A Banks, "Evolution of Ontario Courts 1788 - 1981" in David H Flaherty, ed, Essays in the History of Canadian Law, vol 2 (Toronto: Osgoode Society, 1983) 492 at 498 . The remake of the court into a "People's Court" is a $20^{\text {th }}$ century initiative. Peter H Russell, The Judiciary in Canada: The Third Branch of Government (Toronto: McGraw Hill Ryerson, 1987) at 237-51; George W Adams, "The Small Claims Court and the Adversary Process: More Problems of Function and Form" (1973) 51 Can Bar Rev 583 at 605, 611.

4 In actual not inflation adjusted or proportionate dollars. Limit was set at $\$ 400.00$ by Small Claims Court Act, RSO 1970, c 439, s 54 (Provisional judicial districts had a limit of $\$ 800$; these were less populated northern districts designated under the Territorial Division Act, RSO 1970, c 458); Provincial limit was increased to $\$ 1,000.00$ on November 25, 1977 by the Small Claims Court Amendment Act, SO 1977, c 52; The next increase was to $\$ 6,000.00$, O Reg 92/93 pursuant to the Courts of Justice Act, RSO 1990, c C-43 [Courts of Justice Act]; The limit moved to \$10,000 effective on April 2, 2001 pursuant to O Reg 626/00, and to $\$ 25,000$ effective January 1, 2010 pursuant to O Reg 439/08. Toronto was the subject of a pilot project that moved its limit to $\$ 3,000$ in 1980: The Provincial Court (Civil Division) Project Act, RSO 1980, c 397, s 6.

5 See e.g. Tal Finney \& Joel Yanovich, "Expanding Social Justice Through the People's Court" (2006) 39:2 Loy LA L Rev 769 at 776; Shelley McGill, "Small Claims Court Identity Crisis: A Review of Recent Reform Measures" (2010) 49:2 Can Bus LJ 213 at 217-18; Jacob Ziegel, "Canadian Consumer Law and Policies 40 Years Later: A Mixed Report Card" (2010) 50 Can Bus LJ 259 at 287-92 (evaluating success of consumer access to justice initiatives); John Baldwin, "Is There is a Limit to the Expansion of Small Claims?" (2003) 56:1 Curr Legal Probs 313. Sceptics may suggest limits are raised to reduce back logs in higher courts. 
completion of the study. Parts V, VI and VII describe the results of the data analysis relating to claim volume, claim value and use of representation, respectively. Implications of the findings and suggested questions for further investigation are offered in Part VIII with concluding commentary in Part IX.

\section{EXISTING EMPIRICAL RESEARCH ON SMALL CLAIMS COURT}

Empirical legal research in the area of Canadian civil access to justice has been slow to develop in the decades following the first call for it in $1983 .{ }^{6}$ Still, the lack of empirical support for doctrinal legal research has not deterred commentators from opining on access to justice issues and priorities in court system design. Although the design features of North American Small Claims Court systems vary widely, every provider claims its process advances the court's "access to justice" mandate. ${ }^{7}$ In contrast, academic commentators regularly dispute the access to justice contribution of Small Claims Court, claiming it has deteriorated into a collection agency for business with few self-represented litigants. ${ }^{8}$

Governments collect and release only limited statistical information on Small Claims Court leaving many unanswered questions. For example data from the Ontario Ministry of the Attorney General shows a $15 \%$ drop in the number of claims issued over the five years from 2006 to 2010 with a corresponding increase in time spent on events heard. ${ }^{10}$ This partial release of information raises more questions than it answers, triggering the need for more empirical work.

Most existing empirical studies of Canadian Small Claims Courts date back to the last century and therefore are of limited value in assessing the access to justice issues facing today's courts. ${ }^{11}$ Most studies of the Ontario courts were completed in the 1970s and 80s when the provincial monetary limits did not reach $\$ 1,000$ (approximately $\$ 4,000$ in today's inflation adjusted dollars), fees were a fraction of current levels, representation cost awards were non-existent and Ontario Small Claims Courts were

6 Constance Backhouse, "Revisiting the Arthurs Report Twenty Years Later" (2003) 18 CJLS 33; Michael Lines, "Empirical Study of Civil Justice Systems: A Look at the Literature" (2005) 42 Alta L Rev 887. Canada is not alone in its lack of empirical research on civil justice issues: See Ross Cranston, How Law Works The Machinery and Impact of Civil Justice (Oxford: Oxford University Press, 2006) at 177 (concluding with respect to the British system that "Unfortunately social research and monitoring have not been prominent features of the civil justice system. By comparison with what has been achieved in criminology, research into civil justice is minimal.")

7 See e.g., Ontario Ministry of Attorney General, News Release, "Resolving Law Suits Faster and More Affordably" (11 December 2008), online: Ontario Ministry of the Attorney General <http://www.attorneygeneral.jus.gov.on.ca/english/news/2008/20081211-civil-nr.asp> (announcing limit increase in 2008).

8 John Baldwin, Small Claims in the County Courts in England and Wales: The Bargain Basement of Civil Justice (Oxford: Clarendon Press Publication, 1997) at 89; Marc W Patry, Veronica Stinson \& Steven M Smith, Evaluation of the Nova Scotia Small Claims Court: Final Report to the Nova Scotia Law Reform Commission (Halifax, St Mary's University, 2009) at 9, 85 available at <http://www.lawreform.ns.ca/Downloads/SmallClaimsFinaReportFINAL.pdf $>$; Ziegel, supra note 5 at $291-292$

9 See e.g., Ontario Ministry of the Attorney General - Court Services Division, “Annual Report 2012/2013” at Appendix B1 Court Statistics B50, online: Ontario Ministry of the Attorney General <http://www.attorneygeneral.jus.gov.on.ca/english/about/pubs/courts_annual_12/Court_Services_Annual_Report_FULL_EN.pdf >.

10 Ontario Ministry of the Attorney General - Court Services Division, "Annual Report 2009/2010" at Appendix B1 Court Statistics, online: Ontario Ministry of the Attorney General <http://www.attorneygeneral.jus.gov.on.ca/english/about/pubs/courts_annual_09/Court_Services_Annual_Report_FULL_EN.pdf_>.

11 See e.g., Seana C McGuire \& Roderick A Macdonald, "Tales of Wows and Woes from the Masters and the Muddled: Navigating Small Claims Court Narratives" (1998) 16 Windsor YB Access Just 48. 
franchised businesses. ${ }^{12}$ The oft-cited 1996 empirical study of the Montreal Small Claims Court specifically examined access to the court for the poor - comparing income, gender and ethnic characteristics of the disputants against the general Montreal population. ${ }^{13}$ Although informative, the study has limited application to other Canadian jurisdictions, as the Quebec court has historically low limits $(\$ 1,000$ at the time of study and only $\$ 7,000$ until Dec. 31, 2014), prohibits the use of lawyers, and restricts business access to the court. Its findings do not speak to the key issues of today - high monetary limits, use of legal representatives and business dominance. Most other existing data on usership comes from the United States, where courts also often prohibit lawyers and function at well below Canadian monetary limits. ${ }^{14}$

Canadian empirical work completed in the last decade is heavily opinion survey based with little attention to archival data on usage. A study of the Nova Scotia Small Claims Court conducted for the Nova Scotia Law Reform Commission investigated attitudes about lawyers, limits and process. ${ }^{15}$ It was based upon a very small number of interviews with court staff and judges and surveys mailed to disputants. ${ }^{16}$ The Ontario Government commissioned Civil Justice Reviews in 1996 and 2007 but little attention was paid to Small Claims Court and recommendations favouring limit increases were derived

12 See e.g., Larry Moldaver \& Jerry Herlihy, Consumer Litigation in the Small Claims Courts of Metropolitan Toronto: An Empirical Analysis (Toronto: Osgoode Hall Law School, 1974); Pamela Sigurdson \& Larry Roine, Consumer Redress Mechanisms (Ottawa: Consumer Research Council Canada, 1977); Kai Hildebrandt, Brian McNeely \& Peter Mercer, "The Windsor Small Claims Court: An Empirical Study of Plaintiffs and their Attitudes" (1982) 2 Windsor YB Access Just 87; Patry et al, supra note 8 at 15-20. As to Ontario court's 1970's status as franchised businesses see comments made during the debate of Toronto's pilot: Ontario, Legislative Assembly, Official Report of Debates (Hansard), 31st Parl, 3rd Sess, (18 June 1979) (Patrick Lawlor), online : Legislative Assembly of Ontario $<$ http://www.ontla.on.ca/house-proceedings/transcripts/files_html/18-JUN-1979_L075.htm>: It is an egregious phenomenon. It is the one area in which justice, the courts, that most public of public institutions, was in private hands. With the government members' mania of trying to privatize everything, I can't help but rejoice tonight that they have reversed their position, at least in this particular area and at least in Metropolitan Toronto. In other words, for the first time they are giving cognizance to seeing the public interest in the administration of justice at that lowest level of the courts where a large number of citizens, far more than ever appear in a county or supreme court, have to appear in order to have justice administered. To be in the hands of county clerks, who are the owners of their establishment and who are to a considerable extent outside the jurisdiction of the members opposite, who paid their own secretaries, who had bailiffs under their immediate control, is an anachronistic system in the extreme which has perpetuated itself down.

See also Ontario Law Reform Commission, Report on the Administration of Ontario Courts, Part III, (1973) at 349.

13 McGuire \& Macdonald (1996), supra note 1.

14 See e.g. Suzanne Elwell \& Christopher Carlson, "The Iowa Small Claims Court: An Empirical Analysis" (1990) 75 Iowa L Rev 433; Jennifer Long, “Compliance in Small Claims Court: Exploring Factors Associated with Defendants' Level of Compliance with Mediated and Adjudicated Outcomes" (2003) 21:2 Conflict Resolution Quarterly 139; Bruce Zucker \& Monica Herr, "The People's Court Examined: A Legal and Empirical Analysis of the Small Claims Court System" (2003) 37 USF L Rev 315; Finney \& Yanovich, supra note 5 at 770-771; Craig A McEwen \& Richard J Maiman, "Small Claims Mediation in Maine: An Empirical Assessment" (1981) 33 Me L Rev 237 at 261; Neil Vidmar, "The Small Claims Courts: A Reconceptualization of disputes and an Empirical Investigation" (1984) 1 Law \& Soc'y Rev 515 at 519; James Chapman \& Cathy Nguyen, Raising California's Small Claims Jurisdictional Limit: A Qualitative and Quantitative Examination of San Francisco and Ventura County Civil Plaintiffs (Washington, DC: HALT, 2005), (benefit limited for higher court plaintiffs due to disputant characteristics, i.e., business and assignees banned from Small Claims Court (at 15); Not all plaintiffs support higher limits, some argue they will be prejudiced by informality of the process and lack of discovery (at 5-7)).

15 Patry, supra note 8 at 102-103.

16 Ibid at 5 (254 survey responses from individuals). 
from a small sample of interviewed stakeholders, as well as interest group submissions. ${ }^{17}$ The most recent Quebec study of archival data on Small Claims Court disputes confined itself to examination of construction disputes that were publicly reported after adjudication. ${ }^{18}$ Naturally reported cases generated only a small sample for researchers. Finally, the 2010 study of Middle Income Access to Justice in Ontario, completed for the Law Foundation of Ontario, did not isolate Small Claims Court from Superior Court when respondents from the general public (earning less than $\$ 75,000$ ) were questioned about their attitude towards the court system. ${ }^{19}$

The limited breadth and depth of existing empirical data led the author to seek and obtain Social Sciences and Humanities Research Council of Canada (SSHRC) funding for a study of claims filed in the Ontario Small Claims Court where businesses, corporations and legal representatives are welcomed participants and monetary limits are on the rise. Without current empirical data, "the conclusions that can be drawn about public perceptions [of justice] are both modest and tentative" ${ }^{20}$ It is hoped that this paper helps to fill the void.

\section{THE SMALL CLAIMS COURT ENVIRONMENT}

The province of Ontario is the most active Canadian small claims jurisdiction issuing approximately 63,000 claims annually. ${ }^{21}$ The Ontario Small Claims Court allows both legal representation and business/corporate plaintiffs, ${ }^{22}$ its $\$ 25,000$ limit is not even the highest limit in the country. ${ }^{23}$ Toronto, a diverse and densely populated urban setting, is the highest volume Small Claims Court region within Ontario, issuing over 15,000 claims per year, (approximately $25 \%$ of all Ontario claims). ${ }^{24}$

17 Ontario Ministry of the Attorney General, Civil Justice Review, "First Report, Supplemental and Final Reports", (Ontario Civil Justice Review Committee, 1995), online: Ontario Ministry of the Attorney General

$<$ http://www.attorneygeneral.jus.gov.on.ca/english/about/pubs/cjr/>; Honourable Coulter Osborne, Civil Justice Reform Project Report (Ontario Ministry of the Attorney General 2007), online: <http://www.attorneygeneral.jus.gov.on.ca/english/about/pubs/cjrp/Default.asp>.

18 Cecile Pilarski, Consumers' Use of Small Claims Court in Construction Disputes (Montreal: Association des consommateurs pour la qualite dans la construction (ACQC), 2013), online: ACQC $<$ http://acqc.ca/wpcontent/uploads/2013/11/REV-GFC_Petites-cr\%C3\%A9ances-rapport-Eng22-IS.pdf> .

19 Ontario Civil Legal Needs Project Steering Committee, Listening to Ontarians: Report of the Ontario Civil Legal Needs Project, (Toronto: Ontario Civil Legal Needs Project Steering Committee, 2010), online: Law Society of Upper Canada $<$ http://www.lsuc.on.ca/media/may3110_oclnreport_final.pdf $>$ (hereinafter referred to as OCLN).

20 Michael Lines, "Empirical Study of Civil Justice Systems: A Look at the Literature" (2005) 42 Alta L Rev 887 at para 37.

21 Ministry of the Attorney General (MAG), “Ontario Court Services Annual Report 2011-2012”, online: MAG $<$ http://www.attorneygeneral.jus.gov.on.ca/english/about/pubs/courts_annual_11/Court_Services_Annual_Report_FULL EN.pdf $>$ at 35 .

22 Courts of Justice Act, supra note 4 at s 26 (law society licencees will include lawyers, paralegals, articling students). Most Canadian provinces and territories are the same - except Quebec which excludes both lawyers and corporations.

23 Alberta was the first to raise its limit to $\$ 25,000$ and effective August $1^{\text {st }} 2010$, raised its limit to $\$ 50,000$, the highest limit in the country: Alta Reg 139/14.Yukon has the second highest at $\$ 35,000$. Quebec typically maintained low limits only raising its \$7,000 limit to $\$ 15,000$ on Jan 1, 2015: Code of Civil Procedure, RSQ C-25 2015, art 953.

24 Court Services Annual Reports, supra notes 9, 10, 21. 


\section{A. Overview of Toronto Small Claims Court}

The Toronto Small Claims Court operates from a single self-contained location (at 47 Sheppard Ave.) which afforded the researchers easy file access and reduced the number of administrative approvals necessary to undertake the study- other similar volume regions in Ontario operate as many as 9 different court locations that are integrated with family, criminal or higher civil courts. Toronto Small Claims Court litigants have a wide range of choice in representation, with plenty of lawyers and paralegals, and Toronto is host to two law schools with community legal clinics. All of these factors make the Toronto Small Claims Court the most attractive site for the study.

Still, the selection of Toronto as the source of data has its limitations. It is the largest city in Ontario, often considered the financial heart of the country with many head offices located there. It is also the capital of Ontario and the county seat. As a result, government and business may be over-represented among Toronto Small Claims Court litigants when compared to Small Claims Courts in other parts of the provinces. Therefore, future projects will test the findings in other markets. The author considered the high volume and available sample size to be benefits that out-weighed these limitations.

\section{B. Ontario Small Claims Court Civil Procedure}

All Ontario Small Claims Courts follow the same rules of civil procedure. ${ }^{25}$ An Ontario Small Claims Court action is commenced when the plaintiff files a claim and serves the named defendant(s) with it. ${ }^{26}$ Defendants have 20 days to respond by serving and filing a statement of defence or a statement of defence with a defendant's claim. ${ }^{27}$ Thereafter defended actions proceed to a mandatory settlement conference where issues are narrowed, document and witness disclosure is made and settlement is canvassed. ${ }^{28}$ Unsettled matters are set for trial before a Small Claims Court judge. ${ }^{29}$ There is no discovery of witnesses in the process ${ }^{30}$ and rules for admissibility of evidence at trial are relaxed. ${ }^{31}$ Judgments on claims involving more than $\$ 2,500$ may be appealed to the Divisional Court. ${ }^{32}$ Cost awards are typically imposed on a "loser pays" basis and include representation fees not to exceed $15 \%$ of amount claimed. ${ }^{33}$ Unreasonable behaviour or rejected settlement offers may result in the cost cap being exceeded. Forms of available representation include self-representation, family, friends,

25 Rules of Small Claims Court, O Reg 258/98 (total of 22 rules intended to provide a simplified informal process). Key is the limited witness and document discovery.

26 Ibid at rules 7.01, 8.01 (service may be personal or by one of the identified alternatives). Small Claims Court Forms available online at $<$ http://www.ontariocourtforms.on.ca/english/scc/>.

27 Ibid at rules $9.01,10.01$.

28 Ibid at rules $13.01,13.03$.

29 Ibid at rule 13.07; A Small Claims Court Judge, known as a deputy judge, is a lawyer called to the bar in Ontario appointed by the Regional Senior Justice and the Ontario Attorney General for renewable terms of three years to adjudicate Small Claims Court trials on a part-time basis: Courts of Justice Act, supra note 4 at ss 24(2), 32(1).

30 Phillips v Dis-Management, 24 OR (3d) 435; [1995] OJ no 1806 (QL).

31 Courts of Justice Act, supra note 4 at ss 25, 27; See also supra note 25 at rules 18.01-18.02.

32 Courts of Justice Act, ibid at s 31; O Reg 317/11 claims involving less than $\$ 2500$ are not appealable - amount is tied to claim value not judgment value.

33 Courts of Justice Act, ibid at s 29; Rules of Small Claims Court, supra note 25 at rule 19.04; Other jurisdictions such as the United Kingdom see the loser pays rule as a barrier to access to justice: Ross Cranston, supra note 6 at 168. 
employees, or independent representation in the form of agents, collection agencies, paralegals, students-at-law (articling students) and lawyers. ${ }^{34}$

Undefended actions proceed to judgment without further notice to the defendant using one of a variety of processes. Judgment in claims for liquidated damages may be signed by the clerk at the counter or granted by a Small Claims Court judge on an ex parte motion for judgment. ${ }^{35}$ All other claims will be scheduled for an assessment hearing. ${ }^{36}$ If the plaintiff fails to take one of these steps, the file will become dormant and trigger a clerk's order dismissing the claim as abandoned. ${ }^{37}$

Judgments issued in undefended actions (default judgments) may be set aside on motion to a Small Claims Court judge. ${ }^{38}$ Other interlocutory orders obtainable on motion include; extended time for service, substitutional service, and striking the claim or defence. Defendants may admit the claim against them and propose terms for payment without having a judgment signed. Terms of payment hearings are conducted by the Small Claims Court judge, payment terms are ordered and judgment is only entered if there is default in the payment arrangement. ${ }^{39}$

Ontario Small Claims Court offers a variety of tools to collect unsatisfied judgments. Judgment creditors may issue garnishments against wages, bank accounts or other outstanding debts. ${ }^{40}$ Writs of seizure and sale against land may be filed with the Sheriff's office to record a lien against land owned by the judgment debtor and personal property may be seized and sold. Creditors may schedule a Judgment Debtor Examination in front of a Small Claims Court judge to obtain needed detail about the debtor's ability to pay. ${ }^{41}$ Failure to appear at an examination (after proper service) may trigger contempt proceedings.

The collection tools of the Ontario Small Claims Courts are also available to enforce other tribunal orders filed with it. For example, orders issued by the Landlord and Tenant Board (typically for arrears of rent) may be filed with the court and proceed directly to enforcement without a trial. ${ }^{43}$ Similarly compensation orders from provincial offences or criminal courts may be enforced through Small Claims Courts. This is an important distinction drawn in the study between those files opened for adjudication purposes and those opened solely for collection activities. ${ }^{44}$

34 Courts of Justice Act, ibid at s 26; Some changes to categories of allowed representation occurred in 2013 which did not affect the data collection period: O Reg 230/13, s 2 changing rule 1.08. The recognition of paralegals as appropriate representatives in Small Claims Court follows the British lead: Cranston, ibid at 60 (referring to Lay Representatives (Rights of Audience) Order 1999, SI 1999/1225; CPR, PD 27, para 3.2(2))

35 Rules of Small Claims Court, supra note 25 at rules 11.02-11.03.

36 Ibid at rules $11.03(3)(4)$.

37 Ibid at rule 11.1.01.

38 Ibid at rule 17.01.

39 Ibid at rule 9.03 .

$40 \quad$ Ibid at rules 20.06-20.08.

$41 \quad$ Ibid at rule 20.10 .

42 Courts of Justice Act, supra note 4 at s 30; Ibid at rule 20.11.

43 See e.g. Residential Tenancies Act, SO 2006, c 17, s 207.

44 Claim Type was divided into 4 categories a plaintiff's claim alone, a plaintiff's claim that triggered a defendant's claim (meaning a counterclaim), a tribunal order or other. The latter two categories relate to collection files that did not require adjudication. Government statistics on volume do not distinguish these streams. 


\section{METHODOLOGY}

Data was collected on the type of file (adjudication or collection), the monetary value of claim, the subject matter of the claim, the presence of a single or counterclaim, whether the claim was defended or undefended, the outcome (settled, abandoned, dismissed, partial judgment, full judgment, appeal), and interest awarded (pre/post rate), any costs awarded (amount), any enforcement steps taken, and the length of the time in system. ${ }^{45}$

Representation data for each party to the action was tracked at four identified points in the proceeding - at first filing, at the settlement conference, at trial, and at collection proceedings plus an "other" category for miscellaneous attendances such as motions. The type of representation at each of these points was classified into one of nine different categories: Self representation when the identified party acts for itself and eight other categories involving representation by someone other than the named party; family or friend, agent, employee, paralegal, lawyer, articling student, collection agency or other (unknown connection).

All information on the above-described characteristics was found in public documents contained in the physical court file. The files are in paper form ${ }^{46}$ and retrieval of the data required access to current and archived files stored on and off the site of the Toronto Small Claims Court. ${ }^{47}$ When a file is opened by a court clerk it is assigned a number in chronological order based on date of issue and files to be studied were randomly selected using the chronological court file number. ${ }^{48}$ Applying a randomized sampling approach to archival data, 3680 files were identified for review (920 files from each of the years 2008, 2009, 2010 and 2011). Two legal research assistants extracted, coded and recorded most of the data over a four month period from May 1, 2013 to August 31, 2013. ${ }^{49}$ No human interviews were conducted for use in the study and no personal information about litigant's names, addresses, gender or other identifying information was recorded.

For this paper data was sub-divided into 4 sample periods $(2008,2009,2010 \& 2011)$ and used to undertake a difference analysis of the effect of the change in monetary limits on claim volume, value

45 Relevant dispute and disputant characteristics was identified from existing empirical research: Vidmar, supra note 14; Elwell \& Carlson, supra note 14 expanded to incorporate issues discussed in recent access to justice commentary (OCLN, supra note 19). In addition, author's personal familiarity with the documentation filed in Small Claims Court files gained through 20 years as a deputy judge provides the expertise to identify the available information contained in the public files.

46 The Ontario government has a computer system that tracks volume of claims, procedural steps taken, aggregate time spent on events heard and length of time in the system (Court Services Annual Report, see supra notes 9, 10, 21). The author was denied access to the computer files but allowed to access the physical files.

47 The author is grateful to the very helpful staff at the Toronto Small Claims Court.

48 Random sampling approach used STATA's quasi-random number generator with fixed seed values to draw a quasirandom sample with replacement over the file number ranges for each year, then dropped any duplicate file numbers to select the first 920 non-duplicate numbers. The additional files were listed as backups and excess, in the order of selection into the sample, in case files were missing and in case data recording proceeded faster than expected.

49 Luke Sinclair \& Brandon Mattalo - who at the time were first year law students at the University of Western Ontario and Queen's University respectively (both BBA graduates from Wilfrid Laurier University) used Excel spreadsheet - coding is categorizing according to pre-set definitions (full code book on file with the author). 
and disputant legal representation. The study's sample size was set at $5 \%{ }^{50}$ of total files using the average number of files issued annually over the 3 years prior to the study period. ${ }^{51}$

Table 1 - Sample Size ${ }^{52}$

$\begin{array}{llll}\text { Year } & \text { Sampled Files } & \text { Files Issued } & \text { \% Sample Size } \\ 2008 & 905 & 16189 & 5.590 \% \\ 2009 & 888 & 15309 & 5.801 \% \\ \text { Before Total } & 1793 & 31498 & 5.692 \% \\ 2010 & 914 & 18580 & 4.919 \% \\ 2011 & 883 & 15242 & 5.793 \% \\ \text { After Total } & 1797 & 33822 & 5.313 \% \\ \text { Study Total } & 3590 & 65320 & 5.496 \%\end{array}$

The difference analysis ${ }^{53}$ involved a comparison of descriptive statistics and frequency proportions from the before and the after limit increase samples in order to identify changes following the limit increase. Two methods of significance analysis, the Chi-square test ${ }^{54}$ and confidence interval estimations, were applied to assess the importance of any identified changes in the sample as indicators of change in the entire population. For ease of presentation, most of the detailed results of the analysis are presented in Tables located in the Appendices with corresponding bar graphs and charts incorporated into the body of the paper.

\section{RESULTS: CLAIM VOLUME BEFORE AND AFTER THE LIMIT INCREASE}

It is logical to expect an increase in actual number of files issued after the monetary limit rose by $150 \%$ in $2010 .{ }^{55}$ There was little reason to think that any rise would be temporary in nature or would

50 See other studies: Zucker \& Herr, supra note 14; Hildebrant et al, supra note 12 (260 files of 8000). Douglas Lind et al, Basic Statistics for Business \& Economics (First Canadian Edition, McGraw-Hill Ryerson Education, 2004) at 261-63 (describing factors relevant to choosing an appropriate sample size as desired level of confidence, tolerable margin of error and variability of population being studied; authors suggest using a comparable study as a source). The target sample size ( 765 of 15697) would render 3.46 confidence interval (plus or minus margin of error) at $95 \%$ confidence level.

51 Only data on claim volume available prior to study was the Court Services Annual Report and this calculates volume on fiscal not calendar year so numbers vary. The author chose to work from the calendar rather than fiscal year because the monetary limit change was implemented at a calendar year change not fiscal year (January 1,2010). The file number assigned to a file at issue includes a chronological number plus the last two digits of the calendar year in which it was issued. Therefore, it was easy to identify the files issued in each calendar year. The average was 15,697 files per year - a minimum target of 765 files per year.

52 Work proceeded quickly so target was exceeded. Variation between years was due to missing files. Missing files can occur if they are still active or ongoing and are pulled to have a process completed or they may be just lost or retrieved for review by a member of the public.

53 Lind et al, supra note 50 at 5 (definition of descriptive statistics).

54 Ibid at ch 14 - used to identify when there is a significant difference between the observed frequency and expected frequency in data categories - distinguishes between sampling variations and real differences.

55 Peter Adams et al,, Evaluation of the Small Claims Program, vol 1 (Victoria: British Columbia, Ministry of Attorney General, 1992) at ii (reporting a $42 \%$ increase in small claims after new limit; with little drawn from higher court, claims 
differentiate between adjudication or collection files. The suggestion that some litigants with claims over $\$ 10,000$ were already pursuing them in Small Claims Court and abandoning the excess would not rule out a rise in number of claims filed after the increase as litigants with claims exceeding the new limit may do the same. Claim volume is assessed using the entire population of files issued in each year as determined from the chronological file numbers assigned at the time of issue; annual totals are described in Table 2 of Appendix 1.

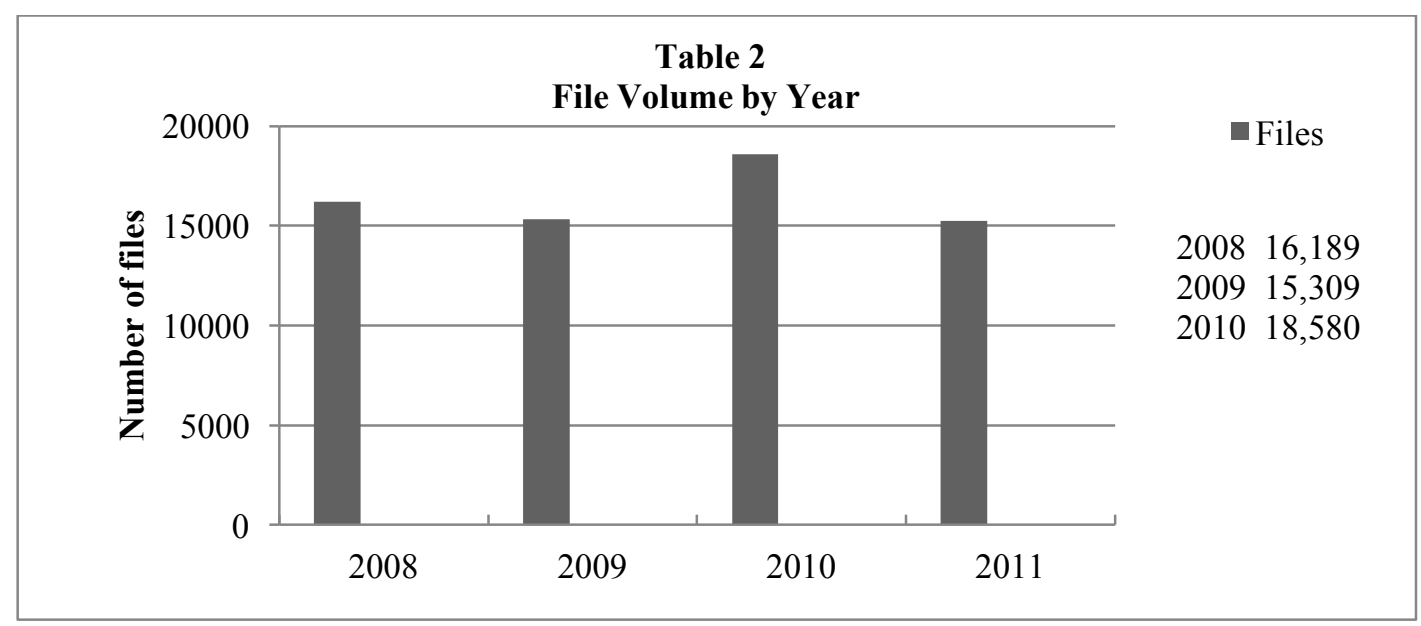

The Court experiences a 2,325 file increase during the post-limit increase sample period representing a $7.382 \%$ rise over the pre-increase volume. However, all of the increase occurs in 2010, the first year of the $\$ 25,000$ limit. By 2011 the file volume drops below the levels of both years in the before sample period, suggesting the rise in volume was temporary. It is possible that some of the 2010 increase may have been files deferred from 2009 in anticipation of the higher limit in 2010. The new limit was announced a year before the January $1^{\text {st }} 2010$ implementation date ${ }^{56}$ and the $5.4 \%$ drop in files issued in 2009 (as compared with 2008) could reflect litigant desire to wait and claim the higher limit. ${ }^{57}$

came "out of the woodwork") cited by Manitoba Law Reform Commission, Report on Review of the Small Claims Court: Executive Summary (Winnipeg: The Commission, 1998) at 3, online: $<$ http://www.gov.mb.ca/justice/ml$\mathrm{rc} / \mathrm{pubs} / \mathrm{smallclaims} . \mathrm{html}>$ (recognizing goal of low cost handling of claims) at 32-33. However, in the month after British Columbia raised its limit from $\$ 10,000$ to $\$ 25,000$ the total number of claims rose by only $15 \%$ but the percentage of claims valued at over $\$ 10,000$ represented $40 \%$ of total claims: "Small Claims Changes", The Williams Lake Tribune (28 October, 2005) 10; British Columbia Ministry of Attorney General, "2006/06 Annual Service Plan Report" (Victoria, British Columbia: The Ministry of the Attorney General, 2006), online: <http://www.bcbudget.gov.bc.ca/Annual_Reports/2005_2006/a-g/ag.pdf/>. When Ontario raised its limit to \$10,000 in 2001/2002 claims rose to 77,466 from 70,462 in the previous year: Ontario Ministry of Attorney General, "Court Services Division - Annual Reports", online: Ontario Ministry of the Attorney General <http:/www.attorneygeneral.jus.gov.on.ca/english/about/pubs/>. See also John Baldwin, Monitoring the Rise of The Small Claims Limit: Litigants' Experiences of Different Forms of Adjudication (London: Lord Chancellor's Department Research Series No 1, 1997$)$ at 96.

56 Ontario Small Claims Reg, supra note 2; Filed: December 10, 2008; Published on e-Laws: December 12, 2008; Printed in The Ontario Gazette: December 27, 2008. It is not suggested that unrepresented litigants reviewed the aforesaid regulation immediately; there were press releases and newspaper articles in the popular press as the January 1, 2010 approached: See e.g., Tracey Tyler, "Ontario Raises the Small Claims Court Limit”, Toronto Star, (11 December 2008$).$ 
Given the 2009 drop and 2010 temporary spike in files, a truer assessment of the impact of the limit increase may come from a comparison of only the years 2008 and 2011; this comparison actually shows a drop in volume of files (947 files) representing a -5.85\% decrease in 2011 from 2008 levels. Recovering economic conditions could be the reason for the lower volume but it is also possible that there is an intimidation factor related to a $\$ 25,000$ limit that actually discourages truly "small" claims. As will be discussed in the next section on claim value - the drop in volume of post limit increase claims is most noticeable in frequency of claims at the lower end of the monetary jurisdiction - claims below $\$ 2,000$.

It is common knowledge that some over limit claims (i.e. worth more than $\$ 10,000$ ) were being issued in 2008 and 2009 and litigants were abandoning excesses over monetary jurisdiction to stay in the simplified low cost Small Claims Court system; however, it is hard to believe that this was being done for amounts more than double the limit. Therefore, it is a surprise that the volume did not increase beyond the first year - the 2010 volume has not re-appeared after the study time period. The Ontario Government's 2012/13 Annual Report indicates Toronto file volume continues at close to before increase levels. ${ }^{58}$ Decreased file volume does not indicate wider access to simplified dispute resolution after the limit increase, although declining volume in civil courts generally is a recognized trend and access to justice issue. ${ }^{59}$

In recognition of the court's dual responsibilities of dispute resolution and collection, the sampled files are sub-divided into two file type categories, one for files seeking adjudication (judgment) in Small Claims Court and the other for matters already with a judgment that are filed for enforcement (i.e. collection) purposes only. ${ }^{60}$ When the combined sample from 2008/09 is compared with the post-limit sample from 2010/11, only a very small difference in relative volume for each category is identified.

57 Naturally, all litigants could not do this for limitation period reasons; the general limitation period for civil cause of action in Ontario is 2 years: Limitation Act, SO 2002, c 24, s 4.

58 Supra note 21 at B50 (values differ as court reports on fiscal year not calendar year) only slight increase after limit increase.

59 Judith Resnik \& Dennis E Curtis, "Representing Justice: From Renaissance Iconography to Twenty-First Century Courthouses" (2007) 151:2 Proceedings of the American Philosophical Society 139 at 170, online: Yale Law School $<$ http://digitalcommons.law.yale.edu/fss_papers/693> (describing a story of "adjudication in decline or, more dramatically, as dying. In both public and private sectors, leaders in many countries argue that private outcomes predicated on the parties' consent are better than those imposed by judges through public processes applying stategenerated regulatory norms. This worldwide movement is propelled by political and social forces trumpeting deregulation and privatization and is staffed by lawyers and other professionals seeking and shaping new markets."); See generally, Marc Galanter, "The Vanishing Trial: An Examination of Trails and Related Matters in Federal and State Courts" (2004) 1:3 J Empirical Legal Stud 459; Canada, Action Committee on Access to Justice in Civil and Family Matters, Report of the Court Processes Simplification Working Group (Canadian Forum on Civil Justice, 2012) at 2, online: $<$ http://www.cfcjfcjc.org/sites/default/files/docs/2013/Report\%20of\%20the\%20Court\%20Processes\%20Simplification\%20Working\%20Group.pdf > (recommending in its vision statement that Canadians should be encouraged to use informal processes of dispute resolution first and seek intervention of the courts second).

60 Researchers coded files into 4 categories based upon initiating documents: plaintiff claim, plaintiff \& defendant's claim, tribunal orders and other. The first two categories reflected adjudication matters and the latter two are collection matters. Collection matters are adjudicated in other forums before they are filed with Small Claims Court for enforcement - they are not to be confused with adjudication files that have as there subject matter an unpaid account or debt. Any claim, no matter the subject matter, seeking a Small Claims Court judgment is coded as an adjudication file. Collection files can have any subject matter including rental arrears or bylaw infraction fines. 
There is only an insignificant decrease in the overwhelming majority of files seeking adjudication rather than collection, suggesting no change in distribution of work across the court's two functions. ${ }^{61}$ Table 3 in Appendix 1 shows the almost identical proportion of adjudication and collection files in both the cumulative ( 2 year) before and after samples.

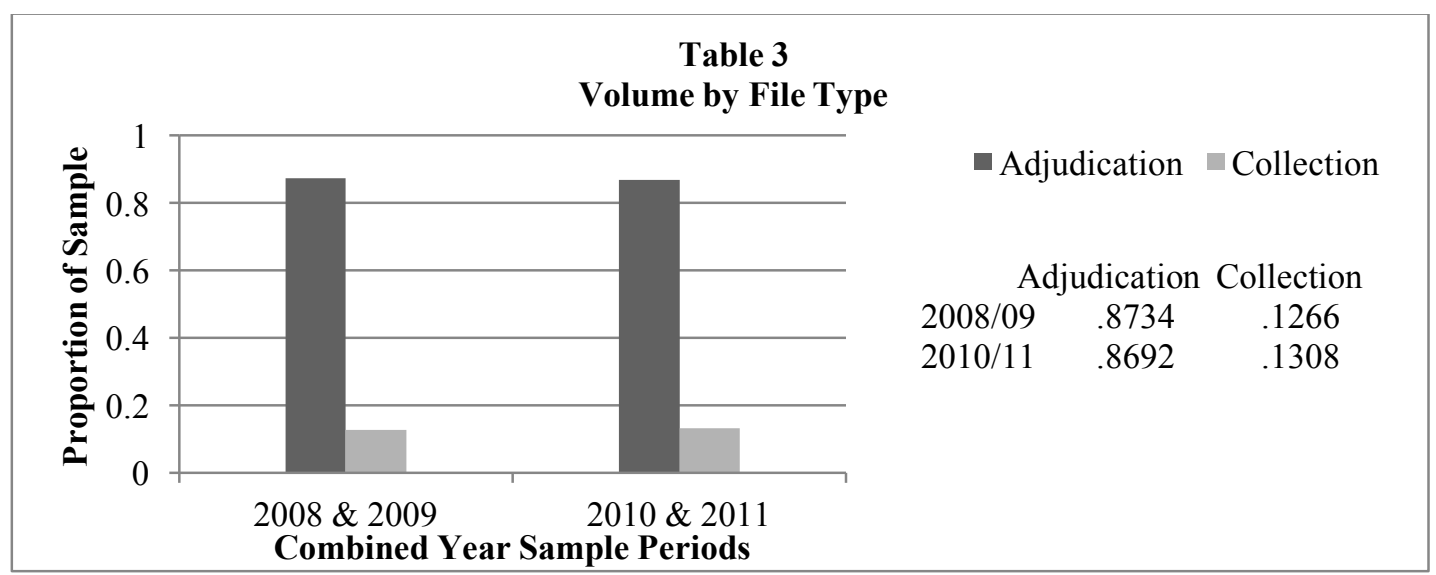

However, when each year's relative frequencies of adjudication and collection files are examined individually, a more complicated picture is revealed.

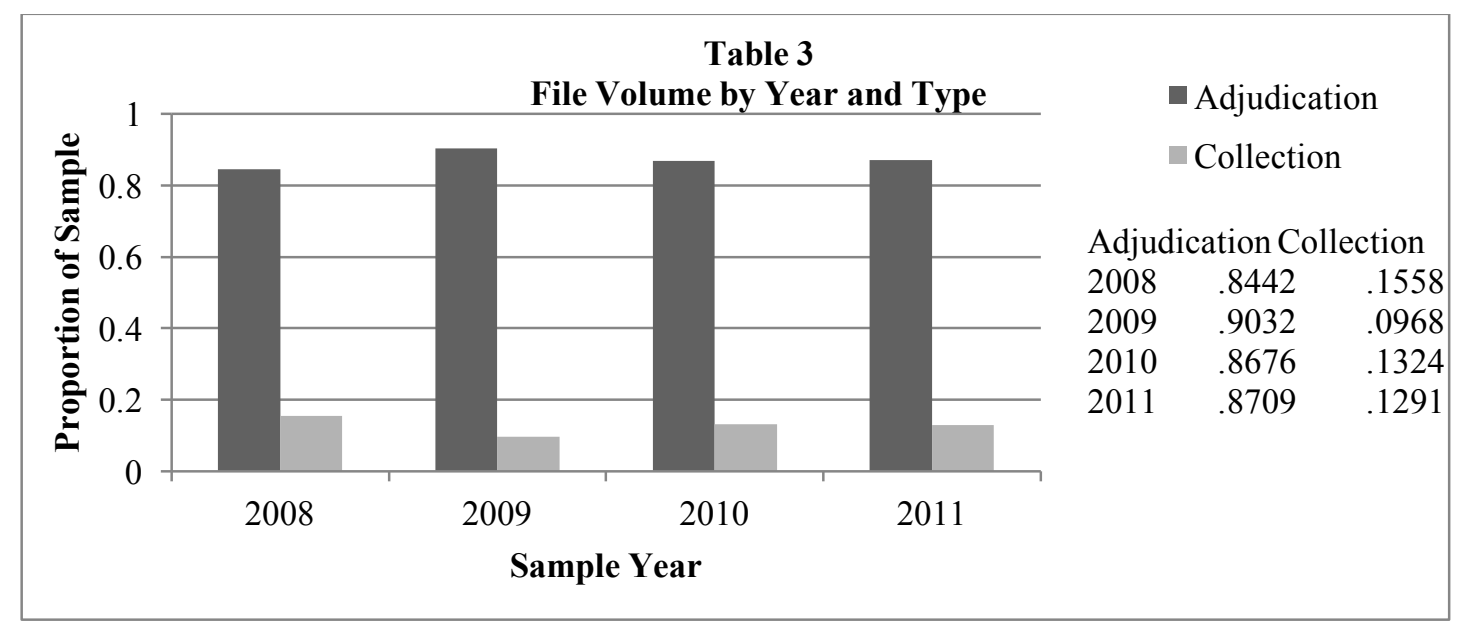

The 2009 proportions are markedly different from those of the 2008, 2010 and 2011, presenting the widest difference between relative frequencies of adjudication and collection files. The 2009 proportion of adjudicative files rises almost $6 \%$ above 2008 sample levels. ${ }^{62}$ The likelihood that this large change

61 Chi-squared test result is .282601 well below the 3.841 needed to reject the null hypothesis of sameness before and after at $95 \%$.

62 Difference between two proportions is 5.9\% with a confidence interval of plus or minus $3.04 \%$ at $95 \%$ confidence: a statistically significant difference that makes consolidating 2008 and 2009 samples inappropriate. Chi-squared test result 
is due to chance or sampling error is very low. Therefore it appears that the 2009 drop in file volume comes from fewer collection files. This strength in adjudicative files is important because it was hypothesized earlier that the 2009 file volume drop may have resulted from tactical decisions to wait until 2010 to seek the benefit of the higher limit. This tactic would only be relevant for adjudication files as collection files have their quantification fixed by other adjudicative bodies prior to filing with Small Claims Court. There would be no advantage to waiting for the next year; delaying could not increase the amount of indebtedness on a collection file. Therefore the drop in proportion of collection files seems less likely to be related to the limit increase than a drop in adjudicative files would have been and adds to the mystery of low 2009 file volume. ${ }^{63}$

In contrast to the pre-limit increase years, the proportions in the post-limit increase years of 2010 and 2011 appear almost completely consistent with each other; maintaining consistent relative frequencies of $86.76 \%$ (2010) and $87.09 \%$ (2011) adjudicative files to $13.24 \%$ and $12.91 \%$ collection, respectively; differences well within confidence interval. ${ }^{64}$

When sample proportions for 2008 alone are compared with those of 2011 alone, we see another different result. Rather than the minuscule decrease in the proportion of adjudication versus collection claims $(-.42 \%)$ seen in the combined before and after samples - we actually see a $+2.67 \%$ rise in proportion of adjudication files, considered a statistically significant change, suggesting a slight change in the distribution of the court's work following the limit change. ${ }^{65}$

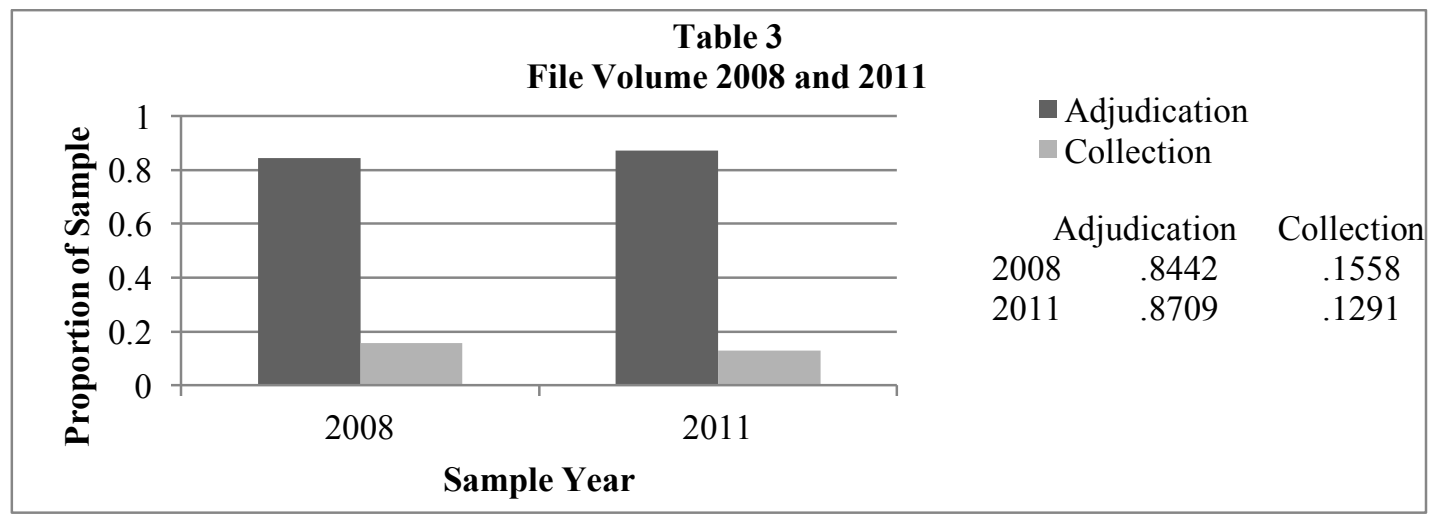

for comparison of 2009 and 2008 proportions is 23.4654 well above the 3.84 needed to reject the null hypothesis of sameness.

63 An unrelated possible reason for a decrease in 2009 collection files could be the uncertainty with respect to contempt and warrant proceedings and the resulting perception that the enforcement processes are ineffective. Between 2006 and 2010 rule changes removed Small Claims Court Judges power to issue warrants of committal weakening the enforcement process. See McGill, supra note 5 at 245-248.

64 Observed proportional difference is $.0033(.33 \%)$ well within the $95 \%$ confidence interval of plus or minus .03125 $(3.1 \%)$.

65 Chi squared test result of 4.7835 exceeds the 3.841 critical value for 1 degree of freedom at $95 \%$; two tailed p-value of .0191 (below .05 for significance). However, observed proportional difference of .0267 has a confidence interval of plus or minus .0326 at $95 \%$ and .0274 at $90 \%$ confidence - both have zero in the interval and therefore still within the confidence interval. 
In sum, the following conclusions can be drawn about claim volumes following the limit increase. First the spike in volume of files experienced in 2010 is not sustained beyond the first year, and volume returns to pre-increase levels and below by 2011 and beyond. The projection that a rise in monetary limit would mean that a greater number of claims would benefit from the Small Claims Court's simplified process is not the reality. Second, just as before the monetary limit increase, the overwhelming majority of the court's work is adjudication rather than collection; adjudication represents well over $80 \%$ in both pre and post samples. Third, there appears to be a slight increase in the proportion of adjudication files in 2011(over 2008 proportions); however, there are alternate possible explanations for this variation. ${ }^{66}$ Generally, the Toronto Small Claims Court appears very similar to its pre-limit increase version with respect to volume of work and distribution of work across its two primary functions.

Most importantly for the purposes of this paper, the analysis of the claim volume data has cast doubt on the usefulness of the 2009 and 2010 sample data, and so, going forward the data from only the 2008 and 2011 samples is used for analysis of claim value and use of representation.

\section{RESULTS: CLAIM VALUE BEFORE AND AFTER LIMIT INCREASE}

Claim value refers to the monetary value assigned to the claim when it is filed with the court, not the adjudicated value after trial. ${ }^{67}$ As noted above, the total 2011 file volume is lower than in 2008 (Table 2) so obviously a rise in mean claim values is predictable - fewer files spread over a larger monetary jurisdiction. The more interesting question is how much higher. This section looks at mean and median values and the distribution of claims across the monetary jurisdiction to determine if standardized claim inflation occurs after the limit increase and whether the same proportion of claims seek the maximum limit in the post-increase sample as before.

Overvaluation of claims is an acknowledged practice in litigation because a court will not award more than is initially claimed and assessing damages is not a precise exercise, ${ }^{68}$ therefore, claim values tend to include a "buffer" above the "real" value. The buffer zone is common for all claims seeking general damages of any value in any court and is typically related to the estimated value of the claim not any particular maximum limit.

Concentration of claims at the maximum monetary limit of Small Claims Court could occur for two other (non-buffer zone) reasons. First, because claims exceeding the limit by only a "small" amount may be more cost effectively processed in Small Claims Court (than the higher level court) and so plaintiffs abandon the excess over the limit and proceed in the lower court. Second, representation cost awards in Ontario Small Claims Court are capped at $15 \%$ percent of the value initially claimed by the plaintiff, not

66 See supra note 63 and accompanying text.

67 Future papers on claim process will look at adjudicated outcomes before and after the limit increase but data points are small for this category because so many claims settle before adjudication and undefended matters typically receive the full value requested.

68 A natural response to the "ultra petita" rule prohibiting a judge from giving a litigant more than asked for in the pleadings; A practice acknowledged to exist in Gordon Shaw v The Queen, [1980] 2 FC 608 at 620, although Justice Walsh found grossly exaggerated claims to be an abuse of process. See e.g. Davies $v$ Corporation of the Municipality of Clarington et al, 2010 ONSC 418 at paras 57-62, 196 ACWS (3d) 1092. 
on the amount awarded. ${ }^{69}$ This cost calculation could act as an incentive to claim the maximum amount even when provable damages are less. ${ }^{70}$

It is important to separate adjudication files from collection files in the claim value analysis because they have different valuation processes. Collection files are assessed in other adjudication forums and their values are fixed before they are filed in Small Claims Court. ${ }^{71}$ The filing party has no discretion with respect to value and so the collection data speaks only to eligibility and access. In contrast, the adjudication file data reflects plaintiff choice about quantification of the claim at the start and relates directly to the question of claim inflation.

The mean and median monetary claim value of adjudication claims rose after the limit increase, as shown on Table 4 of Appendix 2, but nowhere near as much as the proportional $150 \%$ limit increase. The $\$ 9,069$ mean value of the 2011 sample is not quite double that of $2008(\$ 4,676)$. Median values rise a more modest $81 \%$ over 2008 levels. The most common claim value for adjudication files remains the maximum limit in both samples, $\$ 10,000$ and $\$ 25,000$ respectively. $^{72}$ The picture is quite different for collection files where there is virtually no change in mean value following the increase and median value actually falls significantly (see Table 5 in Appendix 2). The following chart illustrates the range ${ }^{73}$ of mean values for adjudication and collection files in their respective sample years.

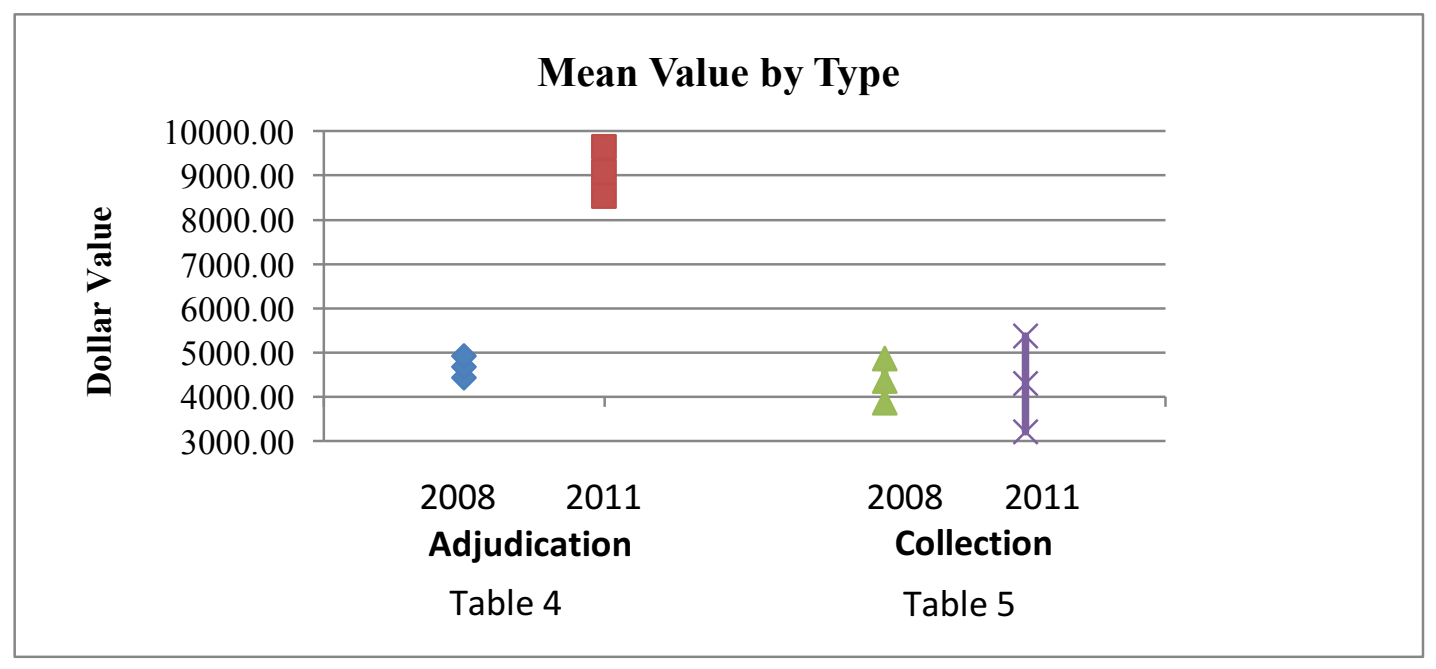

69 Courts of Justice Act, RSO 1990, c C-43, s 29.

70 Achieving partial success can disentitle a party to costs so the strategy here is complicated. It is beyond the scope of this paper to discuss the aspects of Ontario's loser pays rule. Many jurisdictions exempt small claims court from loser pays rule completely and have each party assume their own costs.

71 Separately coded as Tribunal Order and Other during data collection. It is relevant to know if more collection claims are taking advantage of small claims court after the limit increase - and this is addressed in the earlier section on volume. As noted the answer is no - the real number and proportion of collection files is down in 2011.

72 Mode is the value that appeared most frequently in the sample as shown on Table 4, Appendix 2. Lind et al, supra note 50 at 67.

73 The range is the confidence interval at $95 \%$ as described in Tables 4 and 5, Appendix 2 
A statistically significant difference in mean claim value of adjudication files is reflected in the wide gap between value ranges, without overlap, illustrated on the chart above. In sharp contrast is the completely overlapping mean value ranges for collection files.

There is a sizeable drop in median value of collection files (from $\$ 3,862$ in 2008 to $\$ 1,794$ in 2011), surprisingly suggesting that more collection files are concentrated at the very bottom of the jurisdiction than before the increase. As noted earlier this may be due to economic climate or changes in (and dissatisfaction with) the collection process.

The next histogram, compiled from sample results described in Table 6 of Appendix 2, illustrates the similarly shaped proportionate distribution patterns of adjudicative claims across the respective 2008 and 2011 monetary jurisdictions. Despite the general similarity of the shape, there are some important proportional differences after the limit increase. Both samples show concentrations at the top and bottom of the monetary limits but in differing proportions. Predictably, the maximum monetary limit remains the most frequently claimed value (mode) in both the pre- and post-limit increase samples. ${ }^{74}$ Also predictably, the post increase sample is more evenly distributed at the $\$ 10,000$ value than were claims in the before increase sample. The 2008 concentration $(20.31 \%$ of sample) at $\$ 10,000$ (the former maximum limit) naturally evens out across the newly widened value range, showing proportional decrease in concentration of claims of $-14 \%$ plus or minus $3.27 \%{ }^{75}$

More surprising are the changes to the proportion of claims at the top and bottom of the monetary jurisdiction; these fell significantly following the increase in the limit. The concentration of claims at the bottom of the jurisdiction, those valued at $\$ 2,000$ or less, fell from $31.07 \%$ of adjudicative claims filed in 2008 to $19.5 \%$ in 2011 , a statistically significant proportional difference. ${ }^{76}$ It is unlikely that this drop is due to claim inflation at this low end of both jurisdictions as there was room to inflate these values (if need be) even under the former $\$ 10,000$ limit. The drop suggests that litigants with small claims are abandoning the process entirely, following the limit increase. Further research needs to be done to determine where the truly "small" claims are going.

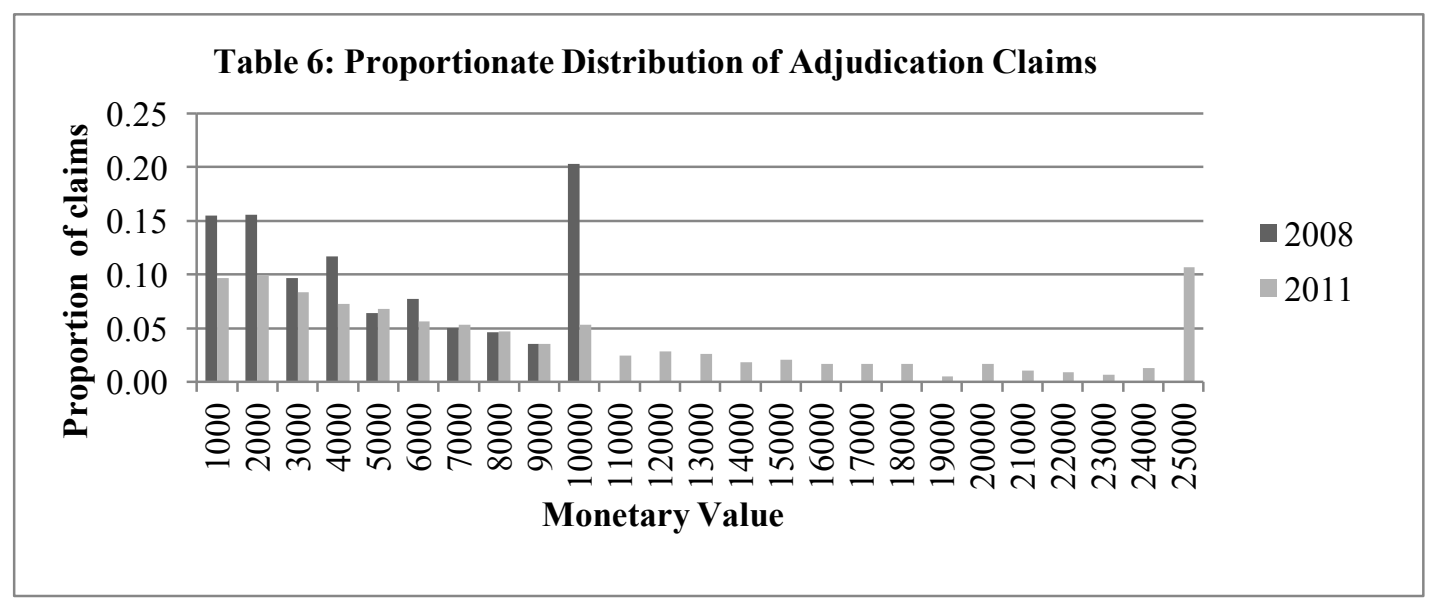

74 See Mode in Tables 4 and 5 in Appendix 2.

75 At $95 \%$ confidence interval estimate.

76 A proportional decrease of $11.56 \%$ plus or minus $4.32 \%$ at a $95 \%$ confidence interval estimate. 
In the 2008 sample, over $20 \%$ of adjudication claims are valued in the top $\$ 1,000$ of the jurisdiction (between $\$ 9,001$ and $\$ 10,000$ ); while in the 2011 sample only $10 \%$ of claims are in the top $\$ 1,000$ (between $\$ 24,001$ and $\$ 25,000$ ). The post increase proportional drop in claims at the top of the jurisdiction can best be compared by looking at the proportion of files that claimed the exact maximum in each time period, $\$ 10,000$ and $\$ 25,000$ respectively. The drop in this concentration is $5.45 \%$ plus or minus $3.33 \%$, again a statistically significant proportional difference following the limit increase. ${ }^{77}$ The reduced concentration at the top of the monetary jurisdiction suggests that fewer plaintiffs are abandoning the excess to stay in Small Claims Court. Possibly the court's simplified process is not viewed as an advantage at this high value level and litigants are content to stay in the higher court (with wider discovery and cost recovery) for amounts over $\$ 25,000 .{ }^{78}$ Future studies could compare relative volume in higher level courts.

In sum, the two functions of the court are reacting differently following the increase in claim value only adjudication is experiencing mean and median increases. There are significant changes in the distribution pattern of adjudicative claims across the monetary jurisdiction following the limit increase, most surprisingly at the top and bottom ends of the range. It appears that fewer maximum claims are being filed after the limit increase, while low valued claims are also disappearing. Claim value is revisited again in the analysis of party representation.

\section{RESULTS: PARTY REPRESENTATION BEFORE AND AFTER LIMIT INCREASE}

A wide range of representation alternatives are available to Small Claims Court litigants. ${ }^{79}$ Prior to 2013 only lawyers, students at law ${ }^{80}$ and agents were identified categories of representatives under the rules. ${ }^{81}$ Historically the label "unrepresented" referred to parties representing themselves or using friends or family, not represented by arms-length legally trained professionals. ${ }^{82}$ The study's representation data was initially coded in 9 different categories with distinctive categories for paralegals

77 Confidence interval estimate of 95\%. 2008 Sample breaks down to 37 files between $\$ 9,001$ and $\$ 9,999$ and 118 at exactly at $\$ 10,000$. The comparison for maximum jurisdiction considers only those claims that claim the maximum exactly: 2008 proportion is .15465 . 2011 sample breaks down to 5 files between $\$ 24,001$ and $\$ 24,999$ and 77 at exactly $\$ 25,000$. The comparison for maximum jurisdiction considers only those claims the claim the maximum exactly: 2011 proportion is .10013 and observed proportional decrease of .054523 from 2008 level.

78 Ontario civil claims valued between $\$ 25,000$ and $\$ 100,000$ have access to a simplified procedure that expands discovery rights and costs provisions while still expedited. It is possible that the availability of this hybrid alternative is reducing the need to abandon the excess and stay in Small Claims Court: Ontario Small Claims Reg, supra note 2 at O Reg 194/90, Rule 76.

79 Courts of Justice Act, supra note 4 at s 26; Law Society of Upper Canada, "Bylaw 4 Licensing", at part v ss 29-30, online: Law Society of Upper Canada <https://www.lsuc.on.ca/by-laws/>.

80 Students at law are articling students - law school graduates who are completing the required internship necessary to obtain a license to practice law under the Law Society of Upper Canada (LSUC) (the Ontario licensing body for both lawyers and paralegals.

81 Since that time the word agent has been replaced with representative which includes lawyers, paralegals and others $\mathrm{O}$ Reg 230/13.

82 Sometimes "unrepresented" is used interchangeably with "self-represented" see e.g. Cicciarella v Cicciarella (2009) 252 OAC 156 paras 35-45, [2009] OJ No 2906 (QL) (discussing leeway to be afforded such litigants). 
and collection agencies in circumstances when license numbers were entered or missing - few data points led to consolidation of some categories as noted below.

Data was collected on plaintiff and defendant representation at four designated "stages in the proceedings:" at the first filing of a document, at the settlement conference, at the trial and at collection. $^{83}$ The sample sizes decline drastically through the stages because most claims go undefended $^{84}$ and defended actions often settle before a trial, or even before a settlement conference. Therefore, this paper uses representation data collected at the first contact, when the claim is commenced by the plaintiff or a defence is filed by the defendant. This is the stage with the largest sample size and also believed to be the point where fewer factors beyond monetary size of the claim influence representation decisions. ${ }^{85}$ This is also the point when the most complete information is available. The data is taken from the initial plaintiff claim form and statement of defence which are prepared by the representative and spaces are provided to designate status of representative and license numbers if applicable. ${ }^{86}$ Therefore, the initial contact with Small Claims Court is isolated as the best and most accurate indicator of representation preference.

The analysis on use of representation is reported in the next three sub-sections: first, combined for all parties, followed by plaintiffs alone and finally, defendants alone. Within each section differences by file type (adjudication and collection) are considered and where possible claim value.

\section{A. All Party Representation}

The results of the comparison of the 2008 and 2011 data on use of representation by all parties (plaintiff and defendant) is reported in Table 7 of Appendix 3 and illustrated in the histogram below. ${ }^{87}$ There are statistically significant changes in the representation distribution pattern after the limit increase. ${ }^{88}$ While the proportion of self-representation remains constant in both samples, the proportions of both key independent legal representatives, lawyers and paralegals, rise significantly in the 2011

83 A fifth "other" category recorded use of representation at motions or other elective proceedings.

84 Of the 905 files in 2008, 141 were collection only files where no defence is filed, leaving 764 adjudication files. The defending proportion is 268 of 764 . For the 883 files in 2011 there are 114 collection files yielding a 285/769 defending proportion.

85 A party's choice of representation type may be influenced by a variety of factors including comfort level with conflict, strength of case, complication of the process, representation of the opposition and claim value; the importance of the non-monetary factors may increase as the matter proceeds through various points of proceedings.

86 The Law Society of Upper Canada (LSUC) licenses both lawyers and paralegals with an identification number. Endorsement records relied upon for identification of representation type at subsequent points of the proceedings are filled out by judges and can lack detail about status of representative, sometimes only noting surnames.

87 On some files there are multiple plaintiffs and/or defendants. Understandably multiple plaintiffs all used the same representative and so one entry was made; where multiple defendants share the same representative one entry was made; where a business owner was sued along with the business and the owner represented himself and the business (one entry of "self" was made (rather than an entry for employee and self). Only where defendants used different representation from each other were double entries made - this amounted to 10 additional entries in both the 2008 and 2011 samples.

88 Chi-square test at $95 \%$ with 8 degrees of freedom of 107.0775 , far greater than the 15.51 critical value and yields two tailed p-value of less than .0001 . 
sample. A significant drop occurs in employee representation - businesses' form of selfrepresentation. ${ }^{89}$

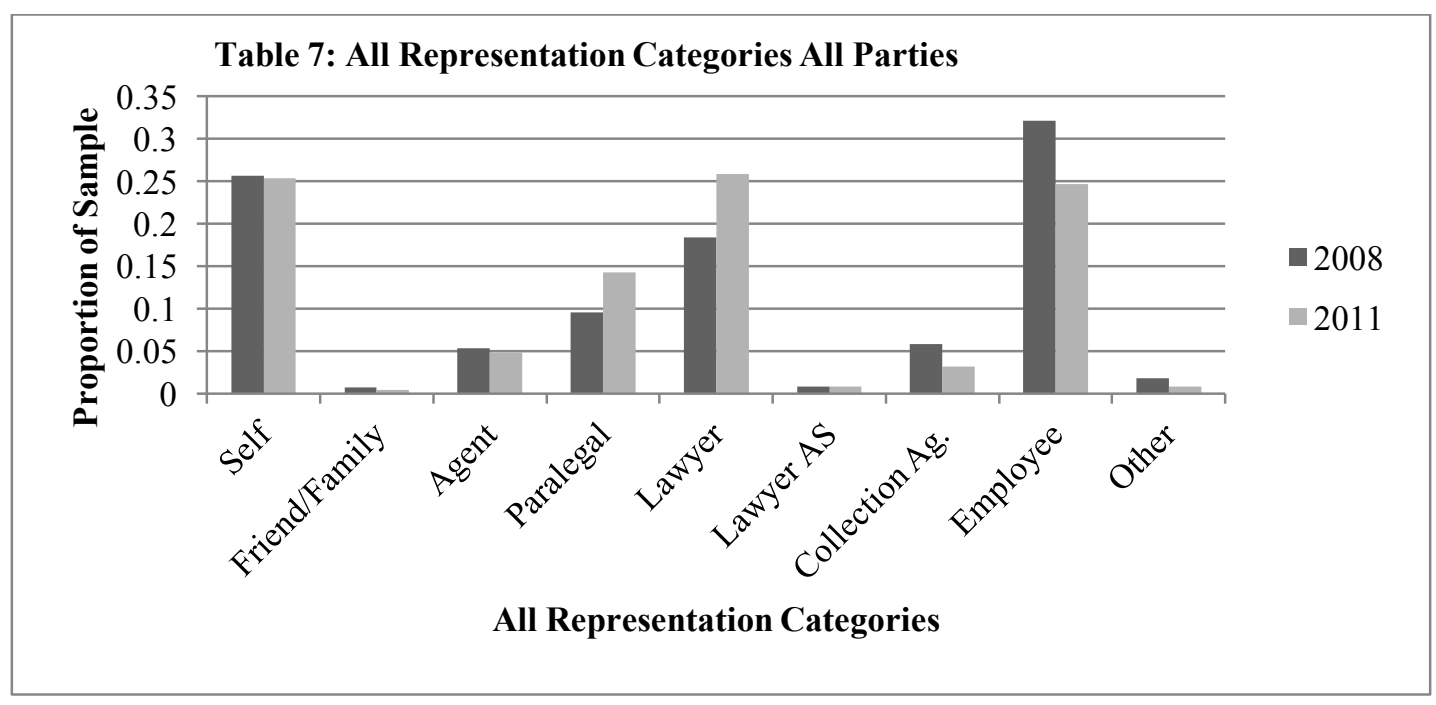

Obvious from the above histogram are the increases in the use of lawyers, paralegals and the decrease in employees after the limit increase. The rise in proportion of lawyers in 2011 is between $4.14 \%$ and $10.81 \%$; the proportion of paralegals rises between $2.15 \%$ and $7.37 \% .{ }^{90}$ The year (2011) over year (2008) percentage increases in lawyers and paralegals are dramatic at $40.74 \%$ and $50 \%$ respectively, and lawyers become the largest representation category in the 2011 sample, between $23.33 \%$ and $28.33 \%$ of all representatives in $2011 .{ }^{91}$

The proportionate decrease in employees after the limit increase almost mirrors that of the increase in lawyers, a decrease between $3.86 \%$ and $11.11 \%$. Employees fall from the largest category of representatives in 2008 to a statistical tie with lawyers and self-representatives in $2011 .{ }^{92}$ The remaining categories showed proportionate decreases that were smaller than the confidence interval (noted with the word "inside" on Table 7); most interesting among the "unchanged' categories is self-representation, holding steady at approximately $26 \%$ of all parties. The unmistakable conclusion is a shift towards legal representation after the limit increase and away from use of employees.

89 Employee category excludes in house counsel (they are coded as lawyers); Employees are typically used by businesses only, such as accounts receivable clerks or managers of the business. Partners and sole-proprietors (owners of the unincorporated business) were coded as self. Confidence interval for observed decrease in proportion of employee representation is plus or minus $.036299(95 \%)$ and $.030456(90 \%)$ so decrease is large enough to conclude at a $95 \%$ confidence that a decrease of between .03847 and .1112 occurred in the overall population.

90 At a $95 \%$ confidence interval - see Table 7 Appendix 3.

91 The confidence interval for the proportion of 2011 lawyers is plus or minus .025 at a $95 \%$ confidence estimate. The sample indicates lawyers as largest group but confidence interval overlaps with those of self, and employees categories. In 2008 the rank order of categories was Employees, Self and then Lawyers, with much larger proportional differences. Therefore even if the 2011 Rank is a three way tie - it marks a significant change for lawyers.

92 Supra notes $90 \& 91$. The confidence intervals for proportions of lawyers, self and employees in 2011 overlap with each other. 
The combined party data displayed in Table 7 is heavily weighted to plaintiffs because litigation has such a high rate of undefended actions. ${ }^{93}$ Therefore the next sections subdivide the data between plaintiffs and defendants. When this is done some of the representation categories have few data points and so are combined to address the central question of whether more parties choose to hire independent professional representation following the limit increase rather than represent themselves. The categories of self and family or friend are consolidated into one named dependent representation (meaning nonarm's length free representation). The categories of lawyer and articling student are combined because articling students by definition work for lawyers. Lawyers, paralegals, agents and collection agencies are consolidated as independent professional representatives (meaning arm's length, trained and paid representation).

For easy comparison with plaintiff and defendant results, Table 8 re-presents the Table 7 data in the three clustered categories. ${ }^{94}$ It shows a clear shift from employees to independent representation, ${ }^{95}$ suggesting that businesses not individuals are changing their choice of representation in the $\$ 25,000$ limit environment. There is a change in rank order of clustered representation categories following the increase. Independent representatives rank first both before and after the monetary increase but employees drop from sole second place to a statistical tie with dependent representatives after the limit increase.

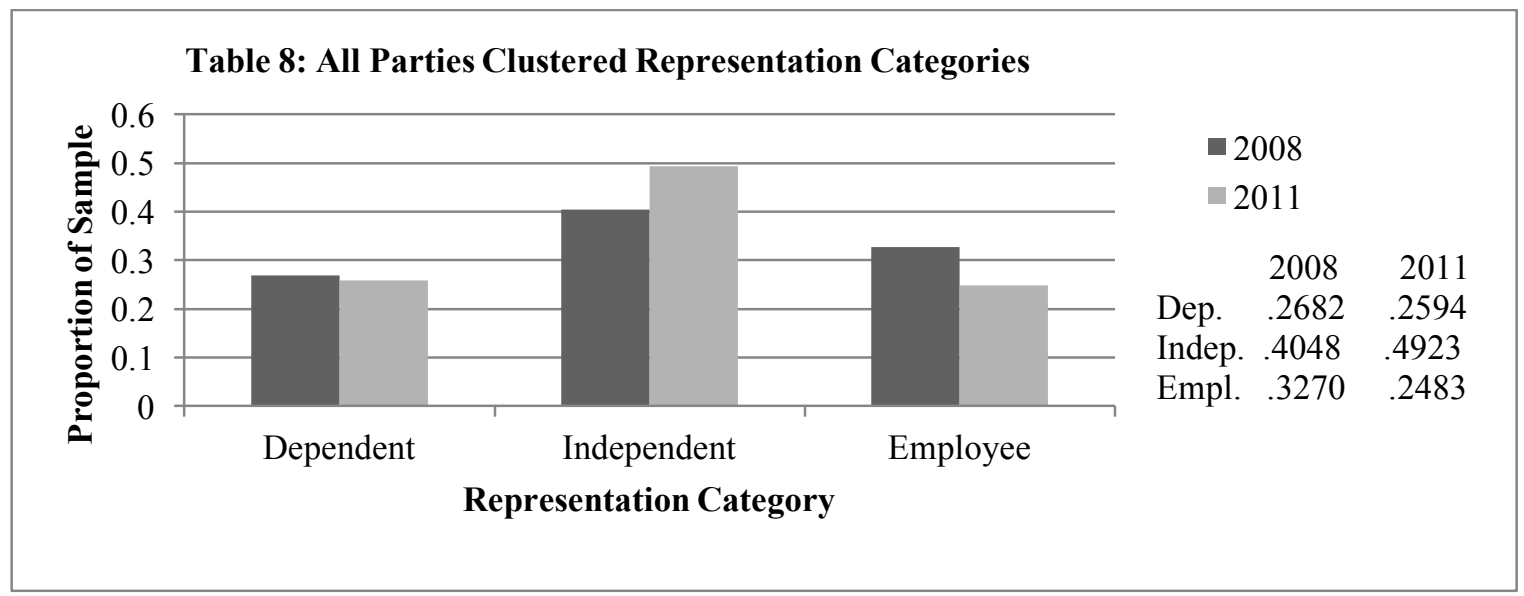

93 Every file has an entry for the plaintiff but only files where a defendant files a defence will have an entry for defendant representation. For 2008 the data reflects 905 plaintiffs and 272 defendants (the rest of the files were undefended) totaling 1177 identified representatives at issue. Of the 905 files, 141 were collection only files where no defence is filed. The defending proportion is 268 of 764 ( 5 file difference comes from multiple defendants on same claim selecting different representations types). For 2011 the 1177 parties are made up of 883 plaintiff representatives and 294 defendant representatives, with 114 collection files yielding a 285/769 defending proportion ( 9 defendants selected different representations from their co-defendant(s)).

Other is removed because files placed here lacked enough information to identify. Sample sizes are accordingly reduced for 2008 down to 1156 and 2011 to 1168 and adjusted expected frequencies are dependent 313.22, independent 472.86, employee 381.92 .

95 Chi-square test resulted in a 44.52178 score, well over the 5.991 score needed to meet $95 \%$ confidence for 2 degrees of freedom. 
The consolidated category for independent representation combines the increase in paralegals and lawyers (although slightly offset by decreases in agents and collection agencies) to show a collective increase in the proportion of independent representation after the limit increase of between $4.72 \%$ and $12.77 \%$, meaning that approximately half of all litigants are independently represented after the limit increase (between $46.36 \%$ and $52.1 \%$ ). ${ }^{96}$

\section{B. Plaintiff Representation}

A plaintiff must either hire someone to commence a claim or do it oneself so the plaintiff representation sample size is the same as the number of files sampled. Commentators expected that fewer plaintiffs would choose self-representation when issuing claims under the new $\$ 25,000$ limit - as high values would justify payment of legal fees and lawyers would be more willing to take high valued cases. ${ }^{97}$ This is not the case.

Plaintiff representation preferences do change after the limit increase but not with respect to the proportion of self-representation, as identified in the comparison of 2008 and 2011 data at Table 9 in Appendix 3, and depicted below. ${ }^{98}$

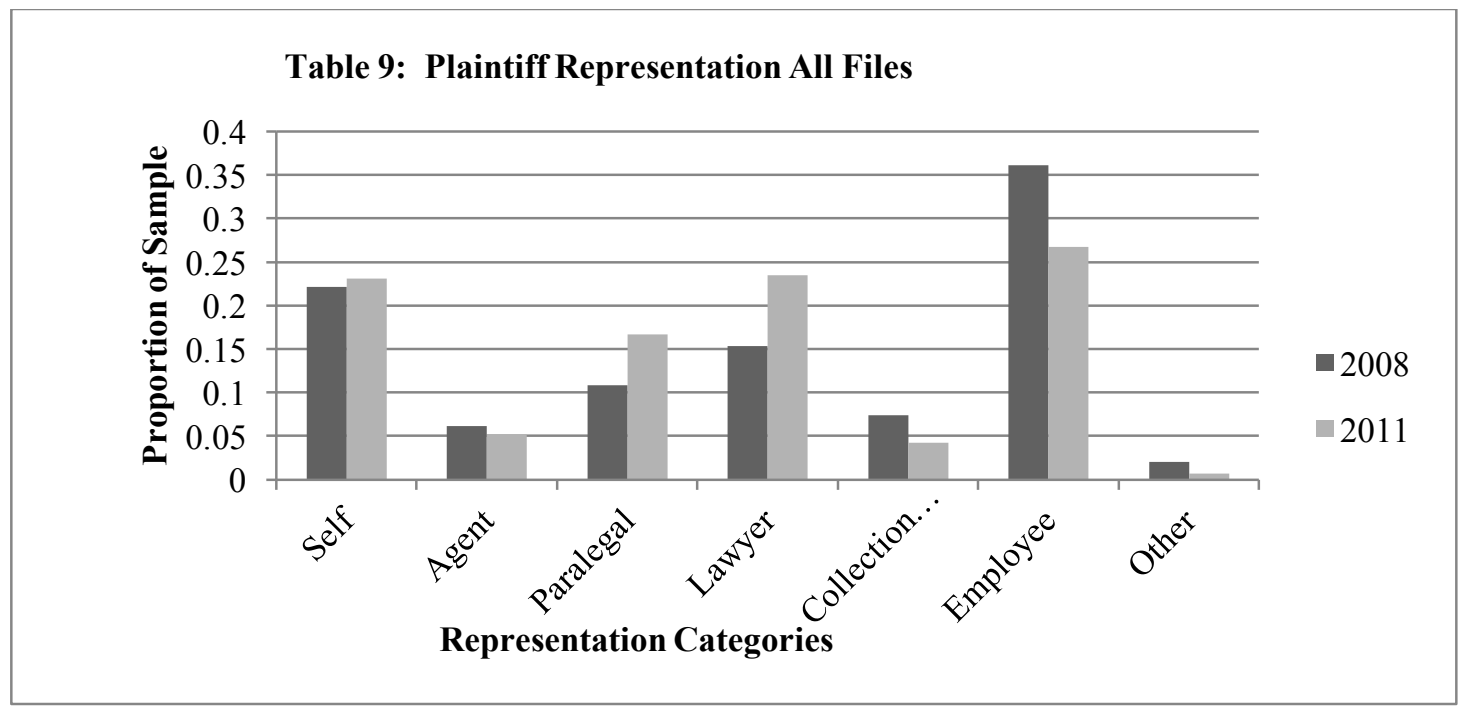

The proportion of self-representation remains steady before and after the limit increase. ${ }^{99}$ Lawyers and paralegals experience greater than 50\% increase over 2008 frequencies. The proportion of lawyers rises between $4.43 \%$ and $11.73 \%$ after the increase and the proportion of paralegals increases between

\footnotetext{
${ }^{96}$ Confidence interval for proportion of 2011 Independent is .028672 at $95 \%$ confidence interval estimate.

${ }^{97}$ See e.g., Finney \& Yanovich, supra note 5 at 773-75.

${ }^{98}$ Results of chi-squared test are 108.4915 with 6 degrees of freedom at a 95\% confidence level, well above the bench mark level of 12.59 and a very small p-value of less than .0001 (well below the .05 level for statistical significance).

99 Proportional increase of .010036 was inside the confidence interval of plus or minus .03878 at a confidence interval estimate of $95 \%$ and also at $90 \%$ (plus or minus .03245).
} 
$2.64 \%$ and $9.0 \%{ }^{100}$ The collection agency representation in 2011 plummeted by $43 \%$ when compared to 2008 levels but its relatively light usage overall results in a proportional decrease of only between $1 \%$ and $5.4 \%$. It is representation by employees that drops significantly in the year over year samples ($26.3 \%$ ), the overall proportion of employees decreases between $5.13 \%$ and $13.69 \%$. In contrast to the rank order of categories in the all parties' data, employees remain the first choice for representation of plaintiffs in both 2008 and 2011. However, lawyers rise to a statistical tie for second with selfrepresentation in 2011. ${ }^{101}$

Table 10 in Appendix 3 displays the Table 9 plaintiff data clustered into the 3 general categories of dependent, independent and employee.

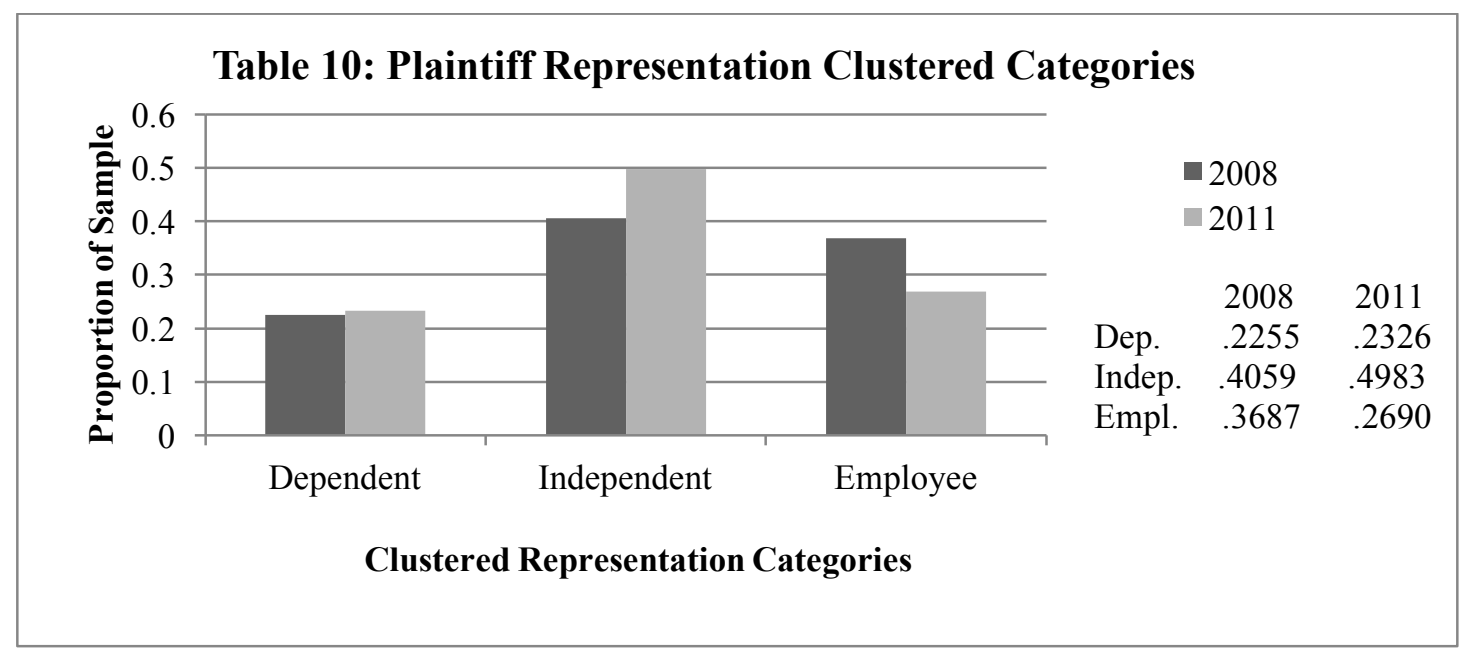

As in the all-party data, the proportion of dependent representation remains constant ${ }^{102}$ while there is a substantial increase in independent and decrease in employee proportions. ${ }^{103}$ The consolidated increase in the proportion of independent representation in 2011 is between $4.62 \%$ and $13.87 \%$ and the decrease in proportion of employee representation is between $5.64 \%$ and $14.28 \%$. The change in frequency of employee representation speaks mainly to the representation preferences of business as only businesses have employees. Business plaintiffs may assign collection responsibilities to a bookkeeper or an accounts receivable clerk. In this light, it is appropriate to consider employees as business's form of self-representation. When employees are viewed as a form of dependent

100 Ontario was one of the first jurisdictions to regulate/license paralegals in 2006: Access to Justice Act, SO 2006, c 21, s 27. Prior to that time they operated in an unregulated environment. It is possible that some of the increase in use of paralegals comes from greater public awareness of the profession in general.

101 The proportional difference between self and lawyer categories narrowed significantly in 2011 - in 2008 the third ranked category of lawyers lagged behind the second ranked category self by .067403 while in 2011 the proportional difference between the two (-.003397) was within the confidence intervals of both proportions.

102 Observed difference of .007 is inside the confidence interval of plus or minus .0392 .

$103 \mathrm{Chi}$-squared test result of 42.237043 far exceeds the standard for 2 degrees of freedom at $95 \%$ confidence (5.991) and pvalue of less than .0001 . 
representation, the proportions of dependent and independent plaintiff representation are statistically equal after the limit increase. ${ }^{104}$

Next, the plaintiff data is subdivided to determine if plaintiffs make different representation choices for adjudicative and collection files ${ }^{105}$ and it appears from the results in Tables 11 and 12 in Appendix 3 that they do. Representation patterns change for plaintiffs on adjudication files after the limit increase ${ }^{106}$ while the data dealing with collection files shows no statistically significant changes after the limit increase.

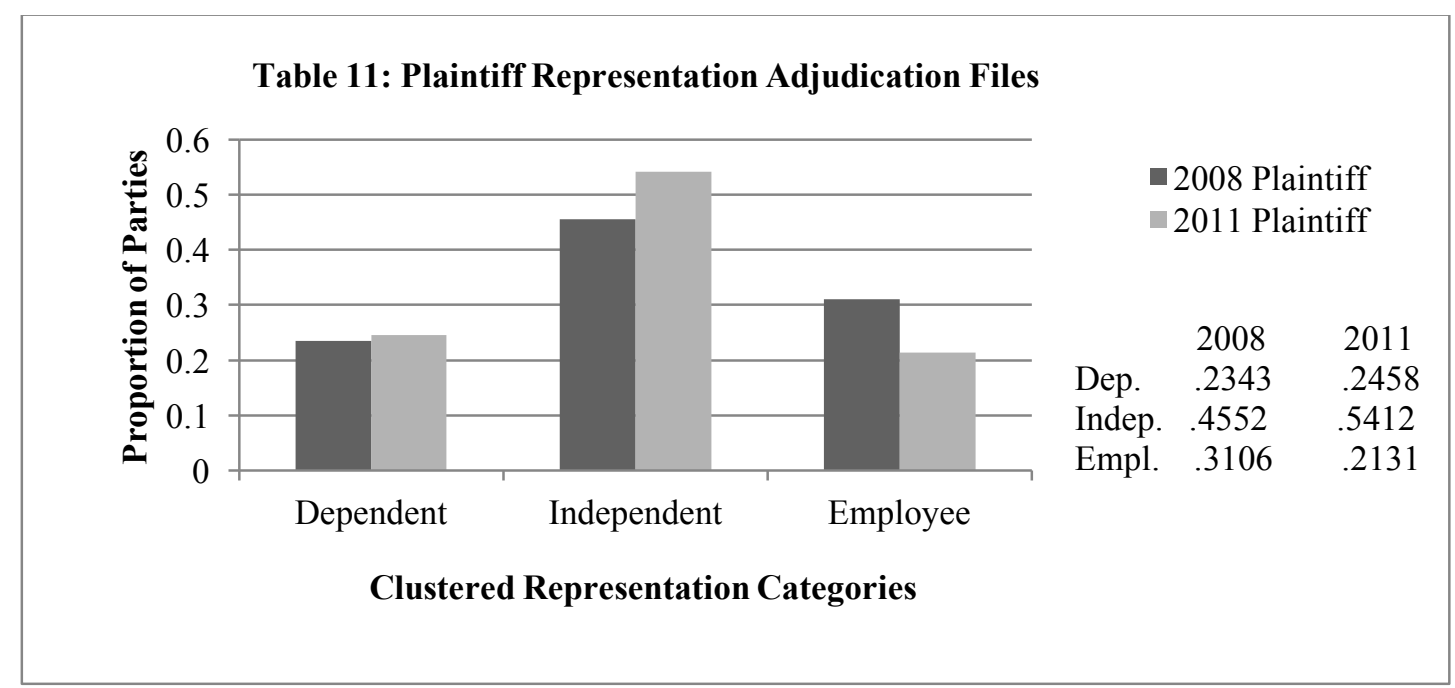

Again, the proportion of dependent representation on adjudication files remains steady ${ }^{107}$ after the limit increase. The differences are in the use of independent and employee representation, similar to their respective increase and decrease in the combined "all files" data of Table 10. It is a different story for collection files, where, despite a sizeable year over year increase in independent representation, all of the 2011 changes on collection files remain within the margin for error. ${ }^{108}$

104 Totaling dependent and employee proportions for 2011 in Table 10 gives a total proportion of .50171 plus or minus .033092 (at $95 \%$ ) and the observed difference with independent (.49829) is only .00342 - well within the both of their confidence intervals. Not so for 2008 data.

105 Sample size of 9052008 plaintiffs divided between 764 adjudication files and 141 collection files. Adjudication files recorded 17 in "other" and collection files had 1 in "other" category - Leaving a 2008 sample size of adjudication files of 747 and 140 collection files. The 2011 plaintiff sample size of 883 divided between 769 adjudication files and 114 collection files, with "other" categories of 4 and 2 respectively, leaving 2011 sample size of adjudication files of 765 and 112 collection files.

106 Result of the chi-squared test is 36.28507 , well in excess of the 5.991 critical value for rejection of the null hypothesis at $95 \%$; p-value of less than .0001. Conclusion is extremely significant.

107 Confidence interval for dependent rep prop difference of .0114812 increase plus or minus .0431 so zero in confidence interval cannot draw conclusion on proportional change.

108 The chi-squared test result is 3.9809211 below both the 95\% score of 5.991 and the $90 \%$ score of 4.605 . Two tailed pvalue of.1366 exceeds .05 significance value. The null hypothesis of equality of the pre and post limit increase proportions cannot be rejected with higher than $.05 \mathrm{p}$-values and such low chi-squared results. 
Unlike adjudication files, the rank order of clustered representation categories on collection files has employees first, both before and after the increase and the signaled change in rank between dependent and independent remains within the confidence interval. Therefore the conclusion is that, following the limit increase, there are significant proportional increases in use of independent representation by plaintiffs in adjudication claims only, not collection matters.

Finally, plaintiff representation data is examined in contrast to claim value to see if plaintiffs with "high" valued claims show an increased proportion of independent representation. The representation pattern of plaintiffs is not independent of monetary value even before the limit increase ${ }^{109}$ Table 13 in Appendix 3 examines the representation pattern of 2008 plaintiffs only, dividing the claims into two categories: ${ }^{110}$ adjudication claims worth $\$ 5,000$ or less and claims of greater than $\$ 5000$. There are higher proportions of lawyers and paralegals involved in claims above $\$ 5,000$ than below; proportional increases are between $10.82 \%$ and $22.46 \%$ and between $6.05 \%$ and $16.35 \%$, respectively, with a now familiar corresponding drop in employee representation. ${ }^{111}$

Similarly in the 2011 sample, there is a noteworthy difference in representation pattern for claims valued over $\$ 12,500$ as compared with claims in the bottom half of the $\$ 25,000$ monetary jurisdiction. ${ }^{112}$ However, unlike 2008, only lawyers (not paralegals) show a proportional increase greater than the confidence interval. As in the 2008 sample, the drop in employee proportion was significant. Interestingly, the proportion of paralegals remains constant across the 2011 sample, the below $\$ 12,500$ paralegals proportion is already at the levels of top half claims in 2008 sample. It appears that paralegals reach a plateau early while the proportion of lawyers continues to rise after the monetary increase. This is an area for future study.

Given that the real dollar range of the bottom half of the 2011 jurisdiction exceeds the entire 2008 jurisdiction (top and bottom), more specific information about whether the limit increase impacts representation even for low valued claims is obtained when real dollar values rather than proportion of jurisdiction are examined so the 2011 data is re-sorted into increments of $\$ 0$ to $\$ 5,000$ and $\$ 5,001$ to $\$ 10,000$. Table 15 in Appendix 3 compares claims valued at $\$ 5,000$ or less in both the 2008 and 2011 samples and finds that different representation patterns exist after the limit increase, even for claims valued at $\$ 5,000$ or less. ${ }^{113}$

109 Chi-squared test results for data in Table 13 score 152.752 , well over 11.07 critical value for $95 \%$ statistical significant with 5 degrees of freedom; p-value of less than .0001.

110 The number of adjudicative claims for 2008 drops from 764 to 763 because, as noted earlier, the coding of one file failed to note a claim value, although it noted a $\$ 1,350$ settled amount and self-representation for both plaintiff and defendant, all other files compared using their issuing value and this is unknown (although likely below $\$ 5,000$ ).

111 Low frequency led to usual clustering of categories for self and Friend/Fam and Lawyer and Lawyer AS. The "other" category was removed and sample size correspondingly reduced. See Table 13 in Appendix 3.

112 Proportions reported and compared in Table 14 in Appendix 3. Chi-squared test results 42.298 is greater than 11.07 needed for $95 \%$ confidence at 5 degrees of freedom.

113 Results of chi-squared test 37.43987 exceeds 11.07 critical value at $95 \%$ with 5 degrees freedom and so the null hypothesis of same 2008 pattern is rejected. 


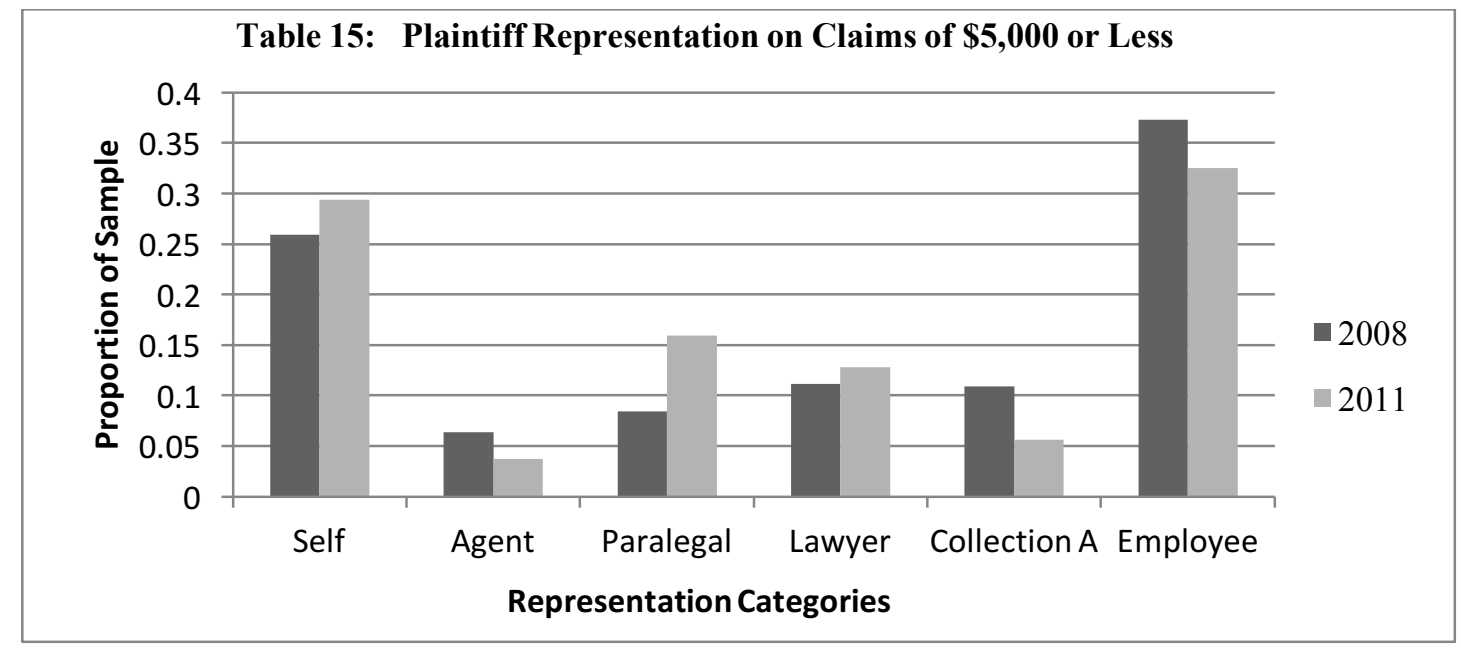

The changes in lawyers, agents, employees and self-representatives are not larger enough to be considered significant. The rise in frequency of paralegals is and indicates an increase in proportion of between $2.75 \%$ and $12.31 \%$ after the new $\$ 25,000$ limit. This gain appears to come from a drop in the use of collection agencies. The fact that there is any change in representation preference at this value of claim is interesting as the same valued claim could be advanced (with the same representation choices available) before the new limit. The significance of the increase in paralegals is masked when broad categories of dependent, independent and employee are compared in Table 16 of Appendix 3 (as paralegals and collection agencies are both within the independent category and their changes offset each other). ${ }^{114}$

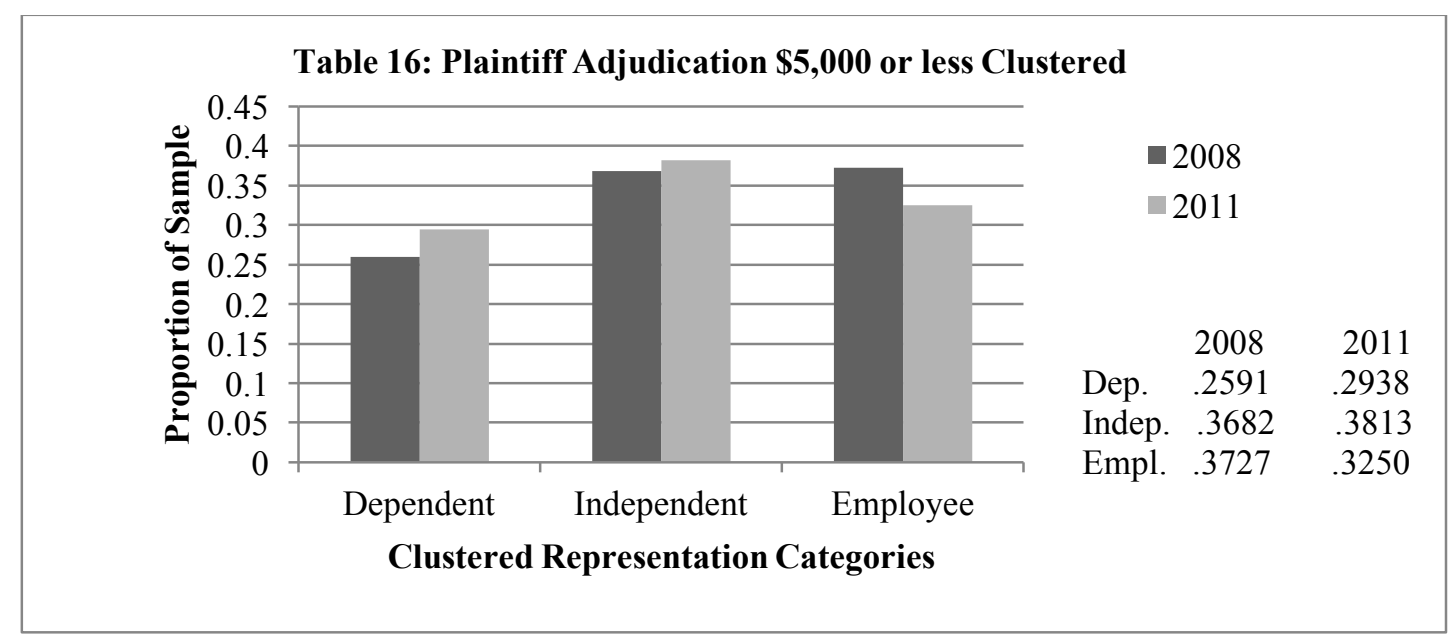

114 Results of chi 3.5877 do not exceed the critical value of 5.991 for 2 degrees of freedom at $95 \%$ confidence estimate. Results reported in Table 16 in Appendix 3 attached. 
Turning to claims in the $\$ 5,001$ to $\$ 10,000$ range, we know that without a monetary limit increase the relative frequency of lawyers and paralegals increases over their proportions in the $\$ 5,000$ and under claims (Table13). The before and after limit increase comparison of claims in this value range does not show a significant change in representation pattern when all representation types are examined individually, as reported in Table 17 of Appendix 3. ${ }^{115}$

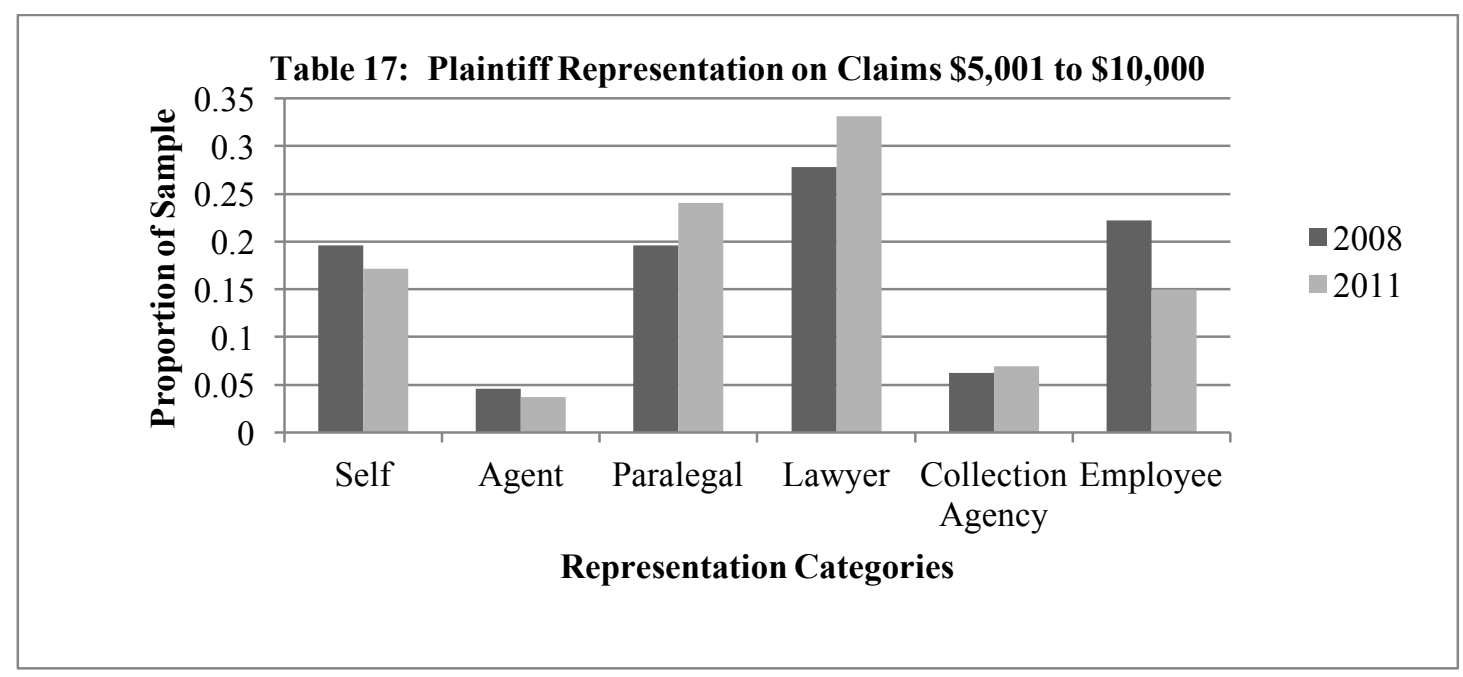

Only employees show a proportional change of any significant size. However, there is upward movement in paralegals and lawyers that becomes significant when lawyers, paralegals, agents and collection agencies are clustered into one Independent category.

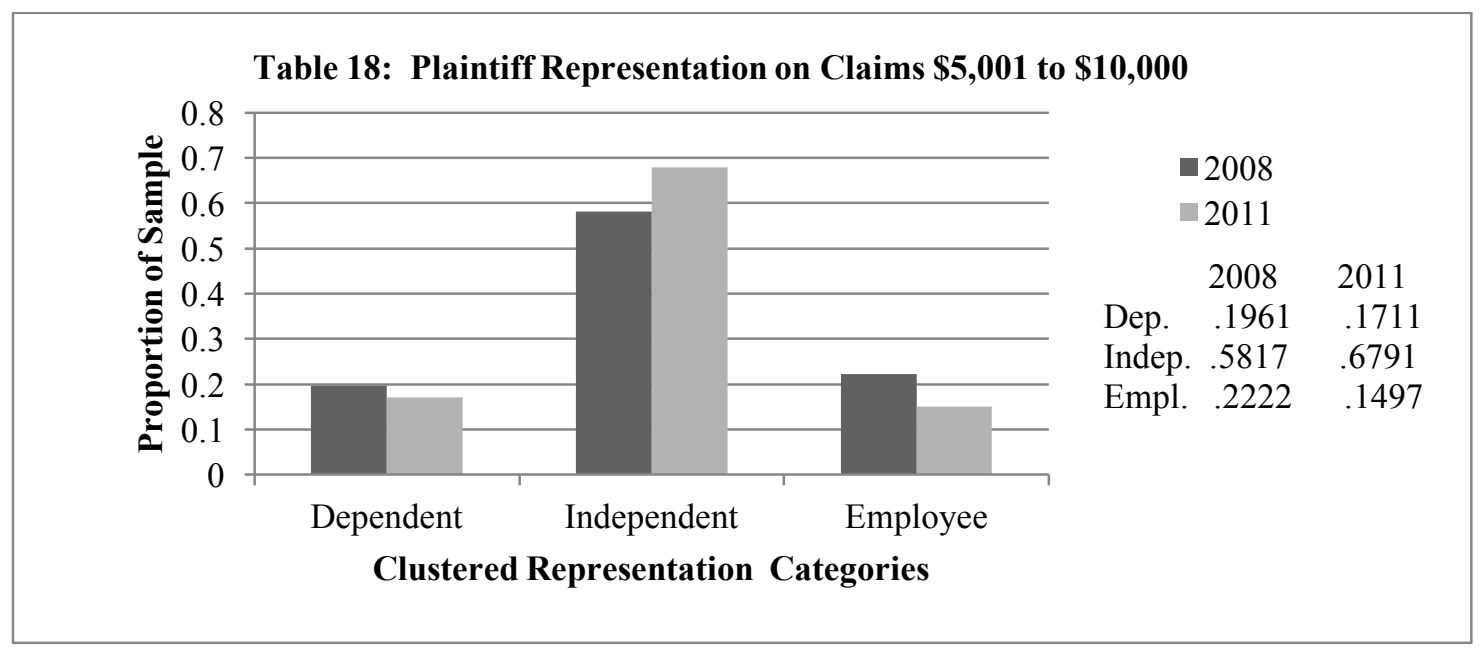

115 Results of chi-squared test is 9.13916 which does not exceed 11.07 critical value for $95 \%$ nor 9.236 for $90 \%$ with 5 degrees of freedom. Results reported in Table 17 in Appendix 3. 
Now there is a measureable difference in the representation pattern after the increase. It is once again driven by the increase in proportion of independent representation and decrease in proportion of employees. ${ }^{16}$ The important conclusion is that plaintiff representation preferences change after the limit increase even for claims valued under the former limit of $\$ 10,000$. Plaintiffs move away from employee representation in favour of independent representation following the limit increase.

\section{Defendant Representation}

As noted earlier, the sample size for defendants is much smaller than for plaintiffs because the vast majority of claims go undefended, ${ }^{117}$ and there is no defendant document filing in claims issued for collection purposes. Defendants must seek special permission from the originating tribunal to re-open a collection file, defending is not part of the Small Claims Court procedure. ${ }^{118}$ Therefore, defendant representation data in Table 19 of Appendix 3 summarizes the representation proportions for defendants filing defences in adjudication files only and is initially presented in the same number of categories as the plaintiff data in Table 9 for ease of comparison. Interestingly paralegals appear in much lower proportions in both before and after samples than they do for plaintiffs. Many categories have very few data points and so for meaningful analysis the data is clustered into the 3 general categories and represented in Table 20 of Appendix 3.

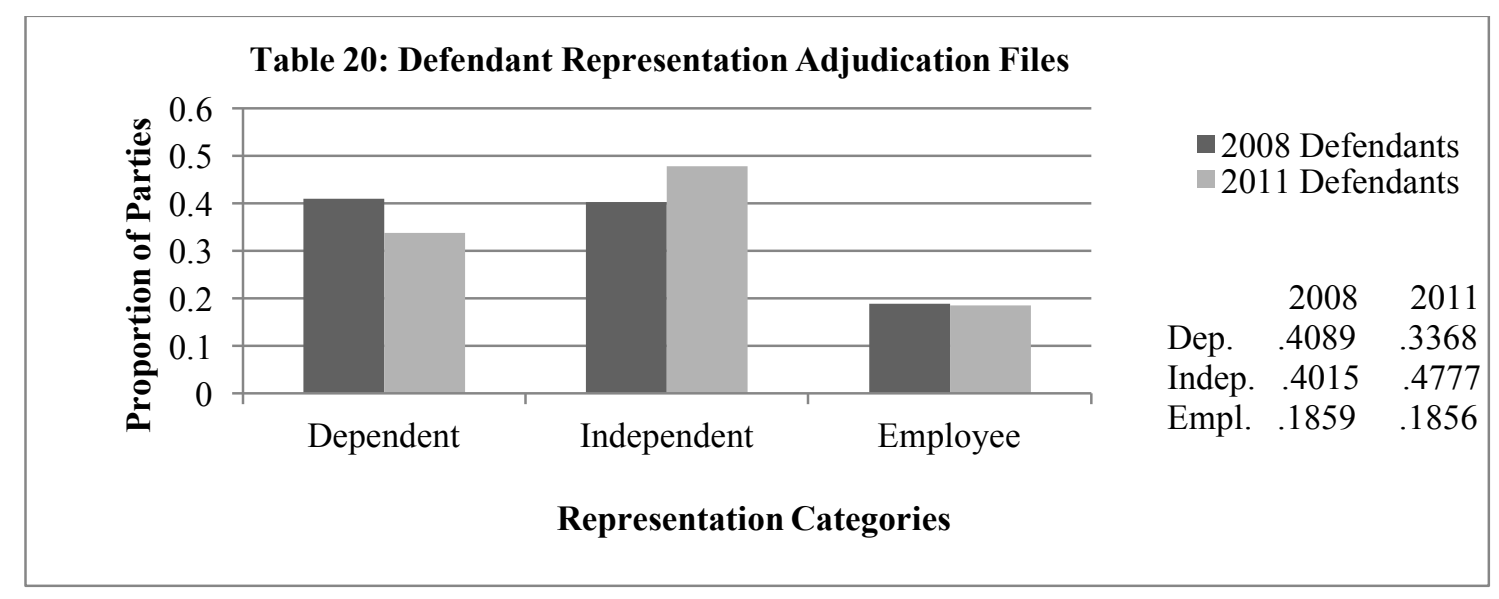

In contrast to the plaintiff results, there is very little change in employee representation after the limit increase, and there is a drop in self-representation; ${ }^{119}$ this result is very different from the all party and plaintiff alone results where the major change is in employee representation.

116 Chi-square test results in 8.068 and exceeds 5.991 critical value for 2 degrees of freedom at $95 \%$ confidence; two tailed p-value is .0177 .

117 See supra note 94 . Study findings to be reported in subsequent paper show majority of claims are not defended (on file with the author).

118 Rules of Small Claims Court, supra note 25 at rule 11.06 (setting aside default applies to Small Claims Court adjudication files only).

119 The small sample size means a wider confidence interval so the proportional decrease of .07215 is only significant at the $90 \%$ confidence level. 
The rank order of representation categories also appears to change for defendants after the limit increase; in the 2008 sample, self-representation ranks first with independent representatives in a virtual tie. ${ }^{120}$ In the 2011 sample, independent representatives take over first place alone ${ }^{121}$ and now represent almost $50 \%$ of all defendants. ${ }^{122}$ The $7 \%$ drop in self-representation is only significant when the lower confidence threshold of $90 \%$ is adopted and therefore we are less sure about its consistency with the actual population than we were with the plaintiff results. ${ }^{123}$ Similarly the independent category shows a significant proportional increase only at the $90 \%$ confidence level; the small proportional decrease in employees is insignificant at both levels.

In sum, there is a change in representation preferences of defendants after the limit increase that is different from the plaintiffs' change - defendants are moving away from self-representatives (rather than from employees). Plaintiff and defendant samples do share a common rate of growth in independent representation following the increase; both experiencing approximately $20 \%$ increase over 2008 levels $^{124}$ to reach approximately half of the litigants. Future papers could examine whether the differences in use of employee representation is due to any dominance of businesses as plaintiffs rather than defendants. For now the variation between party preferences is noteworthy.

Finally, defendant representation and claim value are examined. Just as before, small sample sizes require clustering representation data points into broad categories and lead to wide confidence intervals. However, it is noteworthy that even before the increase, lawyers comprise the largest group within the independent representatives in both claim value ranges. ${ }^{125}$ As with the plaintiff data, independent representation of defendants is higher among claims of higher value even within a consistent monetary limit, as summarized for 2008 in Table 21 of Appendix 3. The 2008 sample shows a dramatic shift to independent representation and away from self-representation in claims valued over $\$ 5,000 .{ }^{126}$ Similarly the 2011 sample data reveals a higher proportion of independent representation for claims valued in the top half of its monetary jurisdiction with a corresponding decrease in self-representation, as set out in Table 22 in Appendix 3. ${ }^{127}$

When the before and after limit increase comparisons are made, unlike plaintiffs, defendant representation proportions change only slightly after the monetary limit increase and the changes are

120 See Table 20 in Appendix 3. The Chi-square test indicates that there are statistically significant changes in defendant representation patterns after the limit increase: Result 7.935457 is greater than critical value 5.991 at 2 degrees of freedom and $95 \%$ confidence level. Two tailed p-value of .0189 is less than the .05 significance level.

122 Proportion of .477663 plus or minus .05739 at 95\% confidence level.

123 Type 2 errors may be more important in this initial study aimed at spotting differences - therefore lower threshold for Type 1 errors (mistakenly rejecting a true hypothesis) will decrease the risk of type two error (failing to reject a false hypothesis).

124 Year Over Year Change Tables 11 and 20, in Appendix 3.

125 Lawyers were 28 of the 39 under $\$ 5,000$ and 54 of the 68 in over 5,000 sample of 2008 files.

126 At $95 \%$ confidence level, chi-squared test results of 47.5452 exceeds the critical value of 5.991 for 2 degrees of freedom at $95 \%$; p-value of less than .0001. See Table 21 in Appendix 3 attached.

127 Chi-squared test result of 50.9644 exceeds critical value 5.991 needed for $95 \%$ confidence with 2 degrees of freedom; two tailed p-value of less than .0001 . 
statistically unimportant for claims in both 0 to $\$ 5,000^{128}$ and $\$ 5,001$ to $\$ 10,000$ ranges. ${ }^{129}$ Again lawyers make up the overwhelming majority of independent representatives in both post limit increase samples. ${ }^{130}$ In sum, it does not appear that representation preferences of defendants change after the limit increase for claims valued at or under the previous limit of $\$ 10,000$. Therefore, the tentative conclusion about defendants' changes in representation after the limit increase made from the all claims data (shown in Tables 19 and 20) must be driven by claims valued over $\$ 10,000$, and therefore in the new expanded monetary limit.

\section{SUMMARY OF FINDINGS, IMPLICATIONS AND FURTHER RESEARCH}

The forgoing analysis offers some important insight into Small Claims Court access to justice from three key perspectives: claim volume, claim value, and party representation. Even where results were predictable, it provides some much needed empirical support for earlier predictions.

System designers can take immediate note of differences between the two functions of the court: adjudication and collection. In all three of the analyzed categories-, volume, value and representation, adjudication and collection files showed different results from each other following the limit increase. Collection files showed far fewer changes in value and representation than did adjudication files. Perhaps the different results for adjudication and collection files justify establishing separate requirements for these two functions of the court.

\section{A. Claim Volume}

First, with respect to claim volume, the data suggests that increasing the monetary jurisdiction of Small Claims Court does not overwhelm the Court with a higher volume of files, nor does it alter the Court's focus on adjudication over collection matters. The temporary first year increase in file volume is not sustained over the two periods of the study (nor in the years since). Therefore, the limit increase has not expanded use of the simplified dispute resolution; Small Claims Court is not resolving a larger number of disputes. Instead, the $\$ 25,000$ limit appears to have re-distributed a similar volume of claims across a broader monetary range. The loss of volume is driven by a drop in collection files rather than adjudication files and the indication is a slight rise in the proportion of adjudication files following the limit increase.

\section{B. Claim Value}

Again the story for claim value is different for adjudication and collection files. Collection values seem oblivious to the new monetary limit - mean values held constant with even greater concentration of claims in the low value levels below $\$ 2,000$ (as reflected by the median value of the 2011 sample).

\footnotetext{
${ }^{128} \mathrm{Chi}$-squared result of 2.123 does not exceed the needed critical value of 5.991 at 2 degrees of freedom for $95 \%$ confidence interval or the $90 \%$ critical value of 4.605. Proportional differences are well within the confidence intervals even at $90 \%$ confidence levels.

${ }^{129}$ Results of chi-squared test are 1.695 well below critical values of 5.991 at $95 \%$ confidence for 2 degrees of freedom or 4.605 for $90 \%$. Proportional differences are well within confidence intervals even at $90 \%$ levels.

${ }^{130}$ For 2011 sample - claims at or under $\$ 5,000$ lawyers make up 21 of the independent representation total and paralegals only 5; for claims over $\$ 5,000$ lawyers make up 20 and paralegals 7 . The very small sample size for 2011 claims in these value ranges reflects the change in volume - fewer claims spread over a wider monetary limit.
} 
Alternatively, and more expectedly mean and median claim values for adjudication files rise significantly $(100 \%)$ following the limit increase. However, still not in proportion to the $150 \%$ increase in the maximum limit. Most importantly the distribution of adjudication claims across the expanded monetary range changes significantly in the post increase time period. The 2011distribution shows less density at the top and bottom of the new $\$ 25,000$ jurisdiction. Fewer claims are "small" claims (below $\$ 2,000)$ and fewer claims seek the maximum jurisdiction in the post increase time period.

The re-distribution of a similar number of claims over a wider range of claim values identifies a direction for future research. In particular, where are the low value (below \$2,000) claims going? How are they being resolved? Why is Small Claims Court no-longer suitable? If the presence of lawyers and high value claims delays and complicates the process, it is possible even small value claims could be discouraged. There is also a question of where the maximum jurisdiction claims have gone. In the past, the simplified process of Small Claims Court has been viewed as an advantage and litigants with claims in excess of the jurisdiction were willing to attorn to the jurisdiction and abandon any excess over it. Has the limit increase removed this perceived advantage? Or perhaps, litigants want a more complex process with full document and witness discovery when claims reach the $\$ 25,000$ range. ${ }^{131}$ System designers should examine these questions when considering limit increases.

\section{Representation}

Arguably the most important finding reported in this paper is that after the monetary increase the proportion of independent representation rises for both plaintiffs and defendants when involved in adjudication of claims, not collection files. The most dramatic increase is in the use of lawyers by plaintiffs, and business appears to be driving this change by hiring independent representatives rather than sending employees to issue their claims. Self-representation among plaintiffs experiences only a modest decline of $3.3 \%$ while employee representation falls by $26.8 \% .{ }^{132}$ This difference between individual and business representation preferences is important because critics feared that selfrepresentation would be a casualty of higher limits. It appears individual (non-business) plaintiffs are staying with self-representation.

There is a difference between the post increase representation patterns of plaintiffs and defendants. Although both parties show an increase in the proportion of independent representation, with the largest proportionate increase being lawyers, defendants seem to be moving away from self-representation rather than employees. In sharp contrast to plaintiffs, defendants show no statistically significant change in the use of employees. Although we can be less certain of this finding given the lower confidence estimate, identifying the possibility is important. Party differences in representation pattern signal mismatched levels of representation and the resulting risk of power imbalances in the court room. If

131 As noted earlier, Ontario's new simplified procedure for claims between $\$ 25,000$ and $\$ 100,000$ may provide a more appropriate balance of process and cost containment. Caution should be exercised here as the simplified procedure was available for claims between $\$ 10,000$ and $\$ 50,000$ in 2008 so a change has still occurred. Ontario Small Claims Reg, supra note 2 at 194/90, Rule 76.

132 Table 10 in Appendix 3, Year Over Year Change. 
faced with repeated mismatched parties, small claims court judges may be tempted to take a more interventionist approach to manage and level the playing field. ${ }^{133}$

There is a higher concentration of independent representatives among claims in the upper half of both monetary jurisdictions, before and after the limit increase, ${ }^{134}$ but for plaintiffs there are even some statistically significant changes in representation for low valued claims following the limit increase. ${ }^{135}$ The proportion of paralegals rises after the monetary limit increase for claims valued at or below $\$ 5,000$. Also for claims in the $\$ 5,001$ to $\$ 10,000$ range, there are statistically significant increases in independent representation and corresponding decreases in employees. ${ }^{136}$ This again speaks to the business plaintiff and a possible uniform policy decision relating to representation in all Small Claims Court matters after the increase, rather than a file by file cost benefit justification to the choice of representation. Defendants show no statistically significant change in representation on low valued claims (claims within the former monetary jurisdiction of $\$ 10,000$ ). This discrepancy in party behaviour is an issue for further investigation.

The implications of more independent representatives generally and lawyers in particular is worthy of more study. Jurisdictions that ban lawyers from Small Claims Court, such as Quebec, do so on the assumption that they detract from the people's character of the court. More professional representation may have an impact on process complexity, value, speed and other access to justice issues such as economic access and likeliness to defend. Further research is necessary to inform system designers before they decide the future of independent representation in Small Claims Court.

\section{Limitations}

Limitations related to the choice of Toronto as the source of data included the very urban setting and its concentration as the financial and government heart of the province, if not the country. These qualities may cause business to be over represented in the sample. Similarly, its position as capital of the province of Ontario may over represent government as a party. The Court's single physical location could be a negative for individual litigant accessibility. It serves a large sprawling population centre and transportation may be a barrier. Although it is virtually on top of a subway stop at Yonge and Sheppard, many parts of Toronto are not on the subway and parking and traffic congestion are negatives. These characteristics mean that Toronto may not be completely representative of all other Small Claims Courts in the province and future studies will test the Toronto findings against other locations. This limitation will be most relevant for this paper's finding on use of independent representation and lawyers. The pool of available lawyers and paralegals will vary across the province. There will be more of both available in Toronto. Still cost could be a factor. Typically, Toronto lawyers charge hourly rates that are higher than

133 See Jona Goldschmidt \& Loretta Stalans, "Lawyers Perceptions of Fairness of Judicial Assistance to Self-represented Litigants" (2012) 30:1 Windsor Y B Access Just 139; Micah B Rankin, “Access to Justice and the Institutional Limits of Independent Courts" (2012) 30:1 Windsor YB Access Just 101 (discussing impartial adjudication and perceptions of judicial bias).

134 Table 13 shows proportion of lawyers on 2008 claims valued over $\$ 5,000$ is .28 as compared to .11 for claims at or under $\$ 5,000$; Similarly Table 14 shows proportion of lawyers on 2011 valued over $\$ 12,500$ is . 38 as compared to .23 for claims at or under $\$ 12,500$. See Tables 21 and 22 for Defendant proportions.

135 Table 15.

136 Table 18. 
the rates charged outside the city. ${ }^{137}$ As a result future studies sampling other geographic jurisdictions are recommended.

\section{CONCLUSION}

Small Claims Court holds an important position in the civil court system. Its simplified civil procedure, relaxed rules of evidence and self-representation make it an example of proportionate justice, alternative dispute resolution and modern access to justice priorities. ${ }^{138}$ As system designers attempt to open its doors to a wider range of claims by increasing monetary limits, the character of the court is changing. This paper finds that there are significant differences in claim value and litigant representation after the Ontario monetary limit increase in January 2010. Although often described as the People's Court, it is changes in business representation behaviour that are shaping the current Small Claims Court environment. Business dominance is not a new criticism of the court; commentators have often lamented the over use of the Court by business. ${ }^{139}$ What is somewhat surprising in this study is that businesses are altering their behaviour under the new higher limits, at least in the area of representation preferences, while individuals are not.

Differences are not uniform across the Court's two processes: adjudication and collection. The Toronto Small Claims Court has not been overwhelmed with higher volumes following the latest monetary increase to $\$ 25,000$; only a temporary spike occurs in 2010 before volume returns to preincrease levels. Wider access to the People's Court has not been realized. There is a minor shift in proportion between adjudication and collection functions. The monetary values of adjudication (not collection) claims have risen dramatically following the limit change and claims are redistributed across the new monetary jurisdiction with a smaller proportion of claims at the bottom and maximum levels of the new monetary range.

Plaintiffs and defendants are both making different representation choices after the limit increase; different from their respective preferences prior to the limit increase and different from each other following the increase. Common to both is the increased preference for independent representatives in the form of lawyers and paralegals, after the limit increase; a change that is confined to adjudication files only.

Post-increase Small Claims Court adjudication is becoming a high stakes activity commonly involving legal representation, while the collection process of the Court carries on as before, with its mean value and representation pattern virtually unchanged. Interestingly, it is business plaintiffs who

\footnotetext{
${ }^{137}$ Mark Wiffen, "The Cost of Litigation in Ontario-Canadian Lawyer Magazine Fee Survey, online: Wiffen Litigation $<$ http://wiffenlaw.ca/blog/item/40-the-cost-of-litigation-in-ontario-canadian-lawyer-magazine-fee-survey $>$; See also Robert Todd, "The Going Rate", Can Lawyer (June 2012) 32, online: www.canadianlawyermag.com $<$ http://www.canadianlawyermag.com/images/stories/pdfs/Surveys/2012/legalfeessurvey2012.pdf> (last visited June 29, 2014).

138 See Action Committee on Access to Justice in Civil and Family Matters, Access to Civil \& Family Justice: A Roadmap for Change (Ottawa: Action Committee on Access to Justice, 2013) at 6, online: Canadian Forum on Civil Justice $<$ http://www.cfcj-fcjc.org/sites/default/files/docs/2013/AC_Report_English_Final.pdf $>$. (Describes six guiding principles for change: (1) put the public first, (2) collaborate and coordinate, (3) prevent and educate, (4) simplify, make coherent, proportional and sustainable (5) take action, (6) focus on outcomes).

139 See e.g. Ziegel, supra note 5 at 291.
} 
appear to be driving the rise in legal representation evidenced by the fall in employee representatives while the proportion of plaintiff self-representation remains constant. The consistent proportion of selfrepresented litigants observed before and after the limit increase may partially justify retention of the People's Court moniker. However, self-representation is only one characteristic typically ascribed to the People's Court, ${ }^{140}$ further study of speed and formality of the process and business dominance in the context of type of party will shed more light on the question of whether the actual usage of the Court under the new higher limit strays even further from its already questionable popular image as a People's Court.

Appendix 1 - Claim Volume

Table 2 - Total Volume Before and After Comparison

\begin{tabular}{|l|l|l|l|}
\hline Years Before & Files Issued $^{141}$ & Years After & Files Issued \\
\hline 2008 & 16189 & 2010 & 18580 \\
\hline 2009 & 15309 & 2011 & 15242 \\
\hline Total Files Before & 31497 & Total Files After & $33822(+7.38 \%)$ \\
\hline
\end{tabular}

Table 3 - Volume for Adjudication vs. Collection Matters

\begin{tabular}{|l|l|l|l|l|l|}
\hline Year & Adjudication & Proportion & Collection & Proportion & Total Sample \\
\hline 2008 & 764 & .8442 & 141 & .1558 & 905 \\
\hline $2009^{142}$ & 802 & .9032 & 86 & .0968 & 888 \\
\hline Total Before & 1566 & .8734 & 227 & .1266 & 1793 \\
\hline 2010 & 793 & .8676 & 121 & .1324 & 914 \\
\hline 2011 & 769 & .8709 & 114 & .1291 & 883 \\
\hline Total After ${ }^{143}$ & 1562 & .8692 & 235 & .1308 & 1797 \\
\hline
\end{tabular}

Definitions - File Type

\begin{tabular}{|l|l|}
\hline Adjudication & Unresolved disputes filed for adjudication in the Small Claims Court trial process \\
\hline Collection & $\begin{array}{l}\text { Final orders filed with Small Claims Court after adjudication completed in other forums such as } \\
\text { administrative tribunals, provincial and criminal courts and filed in Small Claims Court for use } \\
\text { of post judgment collection tools only. Not to be confused with adjudication files seeking to } \\
\text { collect an outstanding debt. }\end{array}$ \\
\hline
\end{tabular}

140 McGuire \& Macdonald, supra note 1 at para 1 (describing the characteristics of the "people's court" as "speed, low cost, informality, self-representation and activist adjudicator" to be available to all citizens regardless of economic status).

141 File volume determined from chronological file numbers issued to claims filed in each calendar year. This is different from the split year fiscal year used by the Ministry of the Attorney General, supra note 9, 21.

142 Chi-squared test result for comparison of 2009 and 2008 proportions is 23.4654 well above the 3.84 needed to reject the null hypothesis of sameness; Difference between two proportions is $5.9 \%$ with a confidence interval of plus or minus $3.04 \%$ at $95 \%$ confidence: A statistically significant difference that makes consolidating 2008 and 2009 samples inappropriate.

143 Chi-squared test result for comparison of Total Before (2008/09) and Total After (2010/11) is .282601 well below the 3.841 needed to reject the null hypothesis of sameness before and after at $95 \%$. 
Appendix 2 Claim Value

Table 4 - Descriptive Statistics for Adjudication Claim Values

\begin{tabular}{|l|l|l|l|}
\hline Claim Value & 2008 & 2011 & Year over Year Change \\
\hline Mean & $\begin{array}{l}\$ 4,676 \quad \text { Confidence } \\
\text { Interval }+/ \$ 240.25\end{array}$ & $\begin{array}{l}\$ 9,069 \quad \text { Confidence } \\
\text { Interval }+/-\$ 555.64\end{array}$ & $+101 \%$ \\
\hline Median & $\$ 3,771$ & $\$ 6,400$ & $+81 \%$ \\
\hline Max & $\$ 10,000$ & $\$ 25,000$ & $+150 \%$ \\
\hline Min & $\$ 53$ & $\$ 128.00$ & $+150 \%$ \\
\hline Mode & $\$ 10,000$ & $\$ 25,000$ & \\
\hline
\end{tabular}

Table 5 - Descriptive Statistics for Collection Claim Values

\begin{tabular}{|l|l|l|l|}
\hline Claim Value & 2008 & 2011 & Year Over Year Change \\
\hline Mean & $\begin{array}{l}\$ 4,365 \text { Confidence } \\
\text { Interval }+/-\$ 599.48\end{array}$ & $\begin{array}{l}\$ 4,297 \text { Confidence Interval } \\
+/-\$ 1081.77\end{array}$ & $-1.56 \%$ \\
\hline Median & $\$ 3,862$ & $\$ 1,794$ & $-53.55 \%$ \\
\hline Max & $\$ 10,000$ & $\$ 25,668$ & $156.88 \%$ \\
\hline Min $^{144}$ & $\$ 0$ & $\$ 0$ & 0 \\
\hline Mode & $\$ 0$ & $\$ 0$ & 0 \\
\hline
\end{tabular}

Table 6 - Adjudication Claim Value Frequency 2008 and 2011

\begin{tabular}{|l|l|l|l|l|l|l|}
\hline $\begin{array}{l}\text { Claim } \\
\text { Value }\end{array}$ & 2008 Frequency & $\begin{array}{l}\text { Proportion of } \\
\text { Sample }\end{array}$ & 2011 & $\begin{array}{l}\text { Proportion } \\
\text { of Sample }\end{array}$ & $\begin{array}{l}\text { Proportional } \\
\text { Difference }\end{array}$ & $\begin{array}{l}\text { Confidence } \\
\text { Interval }(95 \%)\end{array}$ \\
\hline $\mathbf{1 0 0 0}$ & $\mathbf{1 1 8}$ & $\mathbf{. 1 5 4 7}$ & $\mathbf{7 4}$ & $\mathbf{. 0 9 6 2}$ & $\mathbf{- 0 . 0 5 8 4 2}$ & $\mathbf{0 . 0 3 3 1}$ \\
\hline $\mathbf{2 0 0 0}$ & $\mathbf{1 1 9}$ & $\mathbf{. 1 5 6 0}$ & $\mathbf{7 6}$ & $\mathbf{. 0 9 8 8}$ & $\mathbf{- 0 . 0 5 7 1 3}$ & $\mathbf{0 . 0 3 3 3}$ \\
\hline 3000 & 74 & .0970 & 64 & .0832 & -0.01376 & 0.0287 \\
\hline 4000 & 89 & .1166 & 56 & .0728 & -0.04382 & 0.0293 \\
\hline 5000 & 49 & .0642 & 52 & .0676 & 0.0034 & 0.0249 \\
\hline 6000 & 59 & .0773 & 43 & .0559 & -0.02141 & 0.0250 \\
\hline 7000 & 38 & .0498 & 41 & .0533 & 0.003513 & 0.0221 \\
\hline 8000 & 35 & .0459 & 36 & .0468 & 0.000942 & 0.0211 \\
\hline 9000 & 27 & .0354 & 27 & .0351 & -0.00028 & 0.0185 \\
\hline $\mathbf{1 0 0 0 0}$ & $\mathbf{1 5 5}$ & $\mathbf{. 2 0 3 1}$ & $\mathbf{4 1}$ & $\mathbf{. 0 5 3 3}$ & $\mathbf{- 0 . 1 4 9 8 3}$ & $\mathbf{0 . 0 3 2 7}$ \\
\hline
\end{tabular}

144 Zero can and obviously does occur in collection matters when the judgment is for return of personal property and judgment does not assign it a value. This can be return of personal property of sentimental value only; it can also occur when the defendant has been successful defeating a claim and was awarded costs. The collection may relate to a cost award only. The mode as zero is because these claims have already been adjudicated elsewhere so the figures are not typically round estimations but exact calculations and therefore will be more individualized. For example the zero value occurs only three times in 2011.

145 Breaks down to 37 files between $\$ 9,001$ and $\$ 9,999$ and 118 at exactly at $\$ 10,000.2008$ proportion of files claiming the maximum is .15465 


\begin{tabular}{|l|l|l|l|l|l|l|}
\hline 11000 & & & 19 & .0247 & & \\
\hline 12000 & & & 22 & .0286 & & \\
\hline 13000 & & & 20 & .0260 & & \\
\hline 14000 & & & 14 & .0182 & & \\
\hline 15000 & & & 16 & .0208 & & \\
\hline 16000 & & & 13 & .0169 & & \\
\hline 17000 & & & 13 & .0169 & & \\
\hline 18000 & & & 13 & .0169 & & \\
\hline 19000 & & & 4 & .0052 & & \\
\hline 20000 & & & 13 & .0169 & & \\
\hline 21000 & & & 8 & .0104 & & \\
\hline 22000 & & & 7 & .0091 & & \\
\hline 23000 & & & 5 & .0065 & & \\
\hline 24000 & & & 10 & .0130 & & \\
\hline 25,000 & & & 82 & .106 & & \\
\hline Total & 763 & 1 & 769 & 1 & & \\
\hline
\end{tabular}

Appendix 3 Use of Representation

Table 7 - Representation For All Parties at Point of Issue

\begin{tabular}{|l|l|l|l|l|l|l|l|}
\hline Representation & 2008 & $\begin{array}{l}2008 \\
\text { Proportion }\end{array}$ & 2011 & $\begin{array}{l}2011 \\
\text { Proportion }\end{array}$ & $\begin{array}{l}\text { Year over } \\
\text { Year \% change }\end{array}$ & $\begin{array}{l}\text { Proportional } \\
\text { Difference }\end{array}$ & $\begin{array}{l}\text { Confidence } \\
\text { Interval (95\%) + or - }\end{array}$ \\
\hline Self & 302 & 0.256585 & 298 & 0.253186 & -1.3245 & -0.0034 & inside \\
\hline Friend/Family & 8 & 0.006797 & 5 & 0.004248 & -37.5 & -0.00255 & inside \\
\hline Agent & 63 & 0.053526 & 57 & 0.048428 & -9.5238 & -0.0051 & inside \\
\hline Paralegal & $\mathbf{1 1 2}$ & $\mathbf{0 . 0 9 5 1 5 7}$ & $\mathbf{1 6 8}$ & $\mathbf{0 . 1 4 2 7 3 6}$ & $\mathbf{5 0}$ & $\mathbf{0 . 0 4 7 5 7 9}$ & $\mathbf{. 0 2 6 0 8 5}$ \\
\hline Lawyer & $\mathbf{2 1 6}$ & $\mathbf{0 . 1 8 3 5 1 7}$ & $\mathbf{3 0 4}$ & $\mathbf{0 . 2 5 8 2 8 4}$ & $\mathbf{4 0 . 7 4 0 7}$ & $\mathbf{0 . 0 7 4 7 6 6}$ & $\mathbf{. 0 3 3 3 8 2}$ \\
\hline Lawyer AS & 9 & 0.007647 & 9 & 0.007647 & 0 & 0 & inside \\
\hline Collection Ag. & 68 & 0.057774 & 37 & 0.031436 & -45.5882 & -0.02634 & inside \\
\hline Employee & $\mathbf{3 7 8}$ & $\mathbf{0 . 3 2 1 1 5 5}$ & $\mathbf{2 9 0}$ & $\mathbf{0 . 2 4 6 3 8 9}$ & $\mathbf{- 2 3 . 2 8 0 4}$ & $\mathbf{- 0 . 0 7 4 7 7}$ & $\mathbf{. 0 3 6 2 9 9}$ \\
\hline Other & 21 & 0.017842 & 9 & 0.007647 & -57.1429 & -0.0102 & inside \\
\hline Total & 1177 & 1 & 1177 & 1 & & & \\
\hline
\end{tabular}

Table 8-All Parties At Point of Issue - Clustered Categories

\begin{tabular}{|l|l|l|l|l|l|l|l|}
\hline Representation & 2008 & $\begin{array}{l}2008 \\
\text { Proportion }\end{array}$ & 2011 & $\begin{array}{l}2011 \\
\text { Proportion }\end{array}$ & $\begin{array}{l}\text { Year over Year } \\
\text { change }\end{array}$ & $\begin{array}{l}\text { Proportional } \\
\text { Difference }\end{array}$ & $\begin{array}{l}\text { Confidence } \\
(95 \%)+\text { or - }\end{array}$ \\
\hline Dependent & 310 & 0.268166 & 303 & 0.259418 & $-3.30 \%$ & -0.00875 & .035833 \\
\hline Independent & $\mathbf{4 6 8}$ & $\mathbf{0 . 4 0 4 8 4 4}$ & $\mathbf{5 7 5}$ & $\mathbf{0 . 4 9 2 2 9 5}$ & $\mathbf{+ 2 1 . 8 3 \%}$ & $\mathbf{0 . 0 8 7 4 5 0}$ & $\mathbf{. 0 4 0 2 8 4}$ \\
\hline Employee & $\mathbf{3 7 8}$ & $\mathbf{0 . 3 2 6 9 9}$ & $\mathbf{2 9 0}$ & $\mathbf{0 . 2 4 8 2 8 8}$ & $\mathbf{- 2 4 . 3 2 \%}$ & $\mathbf{- 0 . 0 7 8 7 0 2}$ & $\mathbf{. 0 5 9 8 4 8}$ \\
\hline
\end{tabular}

146 Breaks down to 5 between $\$ 24,001$ and $\$ 24,999$ and 77 at exactly $\$ 25,000.2011$ Proportion of files claiming the maximum is .10013 and observed proportional difference of .054523 . 
Table 9 - Plaintiff Representation at Issue ${ }^{147}$

\begin{tabular}{|l|l|l|l|l|l|l|l|}
\hline Type & 2008 & $\begin{array}{l}2008 \\
\text { Proportion }\end{array}$ & 2011 & $\begin{array}{l}2011 \\
\text { Proportion }\end{array}$ & $\begin{array}{l}\text { Year over Year } \\
\text { \% change }\end{array}$ & $\begin{array}{l}\text { Proportional } \\
\text { Change }\end{array}$ & $\begin{array}{l}\text { Confidence } \\
\text { Interval (95\%) }\end{array}$ \\
\hline Self & 200 & 0.220994 & 204 & 0.231031 & $4.54 \%$ & 0.010036 & inside \\
\hline Agent & 56 & 0.061878 & 46 & 0.052095 & $-15.81 \%$ & -0.00978 & inside \\
\hline Paralegal & $\mathbf{9 8}$ & $\mathbf{0 . 1 0 8 2 8 7}$ & $\mathbf{1 4 7}$ & $\mathbf{0 . 1 6 6 4 7 8}$ & $\mathbf{5 3 . 7 4 \%}$ & $\mathbf{0 . 0 5 8 1 9 1}$ & $\mathbf{0 . 0 3 1 8 3 7}$ \\
\hline Lawyer & $\mathbf{1 3 9}$ & $\mathbf{0 . 1 5 3 5 9 1}$ & $\mathbf{2 0 7}$ & $\mathbf{0 . 2 3 4 4 2 8}$ & $\mathbf{5 2 . 6 3 \%}$ & $\mathbf{0 . 0 8 0 8 3 7}$ & $\mathbf{0 . 0 3 6 5 0 5}$ \\
\hline $\begin{array}{l}\text { Collection } \\
\text { Agency }\end{array}$ & $\mathbf{6 7}$ & $\mathbf{0 . 0 7 4 0 3 3}$ & $\mathbf{3 7}$ & $\mathbf{0 . 0 4 1 9 0 3}$ & $\mathbf{- 4 3 . 4 0}$ & $\mathbf{- 0 . 0 3 2 1 3}$ & $\mathbf{0 . 0 2 1 5 7 9}$ \\
\hline Employee & $\mathbf{3 2 7}$ & $\mathbf{0 . 3 6 1 3 2 6}$ & $\mathbf{2 3 6}$ & $\mathbf{0 . 2 6 7 2 7 1}$ & $\mathbf{- 2 6 . 0 3}$ & $\mathbf{- 0 . 0 9 4 0 6}$ & $\mathbf{0 . 0 4 2 7 9 7}$ \\
\hline Other & 18 & 0.019890 & 6 & 0.006795 & irrelevant & irrelevant & irrelevant \\
\hline TotalTotal & 905 & 1 & 883 & 1 & & & \\
\hline
\end{tabular}

Table 10 - Plaintiff Representation by Clustered Categories ${ }^{148}$

\begin{tabular}{|l|l|l|l|l|l|l|l|}
\hline Type & 2008 & $\begin{array}{l}2008 \\
\text { Proportion }\end{array}$ & 2011 & $\begin{array}{l}2011 \\
\text { Proportion }\end{array}$ & $\begin{array}{l}\text { Year of Year \% } \\
\text { Change }\end{array}$ & $\begin{array}{l}\text { Proportional } \\
\text { Difference }\end{array}$ & $\begin{array}{l}\text { Confidence } \\
\text { Interval (95\%) }\end{array}$ \\
\hline Dependent & 200 & 0.225479 & 204 & 0.232611 & $3.13 \%$ & 0.007132 & inside \\
\hline Independent & $\mathbf{3 6 0}$ & $\mathbf{0 . 4 0 5 8 6 2}$ & $\mathbf{4 3 7}$ & $\mathbf{0 . 4 9 8 2 9}$ & $\mathbf{2 2 . 5 2 \%}$ & $\mathbf{0 . 0 9 2 4 2 7}$ & $\mathbf{. 0 4 6 2 5}$ \\
\hline Employee & $\mathbf{3 2 7}$ & $\mathbf{0 . 3 6 8 6 5 8}$ & $\mathbf{2 3 6}$ & $\mathbf{0 . 2 6 9 0 9 9}$ & $\mathbf{- 2 6 . 7 \%}$ & $\mathbf{- 0 . 0 9 9 5 6}$ & $\mathbf{. 0 4 3 2}$ \\
\hline Total & 887 & 1 & 877 & 1 & & & \\
\hline
\end{tabular}

Table 11 - Plaintiff Representation (at issue) in Adjudication Files

\begin{tabular}{|l|l|l|l|l|l|l|l|}
\hline Type & 2008 & $\begin{array}{l}2008 \\
\text { Proportion }\end{array}$ & 2011 & $\begin{array}{l}2011 \\
\text { Proportion }\end{array}$ & $\begin{array}{l}\text { Year over } \\
\text { Year \% } \\
\text { change }\end{array}$ & $\begin{array}{l}\text { Proportional } \\
\text { Difference }\end{array}$ & $\begin{array}{l}\text { Confidence } \\
\text { Interval } \\
(95 \%)\end{array}$ \\
\hline Dependent & 175 & 0.23427 & 188 & 0.245752 & $5.02 \%$ & 0.0114812 & inside \\
\hline Independent & $\mathbf{3 4 0}$ & $\mathbf{0 . 4 5 5 1 5 4}$ & $\mathbf{4 1 4}$ & $\mathbf{0 . 5 4 1 1 7 6}$ & $\mathbf{1 9 . 3 6 \%}$ & $\mathbf{0 . 0 8 6 0 2 2 5}$ & $\mathbf{. 0 4 5 8 9}$ \\
\hline Employee & $\mathbf{2 3 2}$ & $\mathbf{0 . 3 1 0 5 7 6}$ & $\mathbf{1 6 3}$ & $\mathbf{0 . 2 1 3 0 7 2}$ & $\mathbf{- 3 2 . 1 5 \%}$ & $\mathbf{- 0 . 0 9 7 5 0 4}$ & $\mathbf{. 0 4 4 1}$ \\
\hline Total & 747 & 1 & 765 & 1 & & & \\
\hline
\end{tabular}

147 The Self categories includes 193 of self and 7 family and friends for 2008 sample and 200 self plus 4 family and friends for 2011 and were collapsed because one entry below 5 - both forms represent non-arms' length unpaid representatives. Lawyer categories include 133 lawyers and 6 articling students for 2008 and 202 lawyers and 5 articling students for 2011.

148 Other category is removed and denominator correspondingly reduced.

149 Adjust expected frequency for 877 sample size is dependent: 197.75, independent: 355.94 and employee: 323.31.

150 Adjusted expected frequencies for 2011 sample size is dependent: 179.22 independent: 348.19 employee: 237.59 . 
Table 12 - Plaintiff Representation (at issue) in Collection Files

\begin{tabular}{|l|l|l|l|l|l|l|l|}
\hline Collection & 2008 & $\begin{array}{l}2008 \\
\text { Proportion }\end{array}$ & 2011 & $\begin{array}{l}2011 \\
\text { Proportion }\end{array}$ & $\begin{array}{l}\text { Year over Year \% } \\
\text { change }\end{array}$ & $\begin{array}{l}\text { Proportional } \\
\text { Difference }\end{array}$ & $\begin{array}{l}\text { Confidence } \\
\text { Interval } \\
(95 \%)\end{array}$ \\
\hline Dependent & 25 & 0.178571 & 16 & 0.142857 & $-20 \%$ & -0.03571 & .0941 \\
\hline Independent & 20 & 0.142857 & 23 & 0.205357 & $43.75 \%$ & 0.0625 & .0933 \\
\hline Employee & 95 & 0.678571 & 73 & 0.651786 & $-3.95 \%$ & -0.02679 & .1153 \\
\hline Total & 140 & 1 & 112 & 1 & & & \\
\hline
\end{tabular}

Table $13-2008$ Plaintiff Representation by Claim Value ${ }^{152}$

\begin{tabular}{|l|l|l|l|l|l|l|}
\hline 2008 & $\begin{array}{l}5000 \quad \text { or } \\
\text { Less }\end{array}$ & Proportion & $\begin{array}{l}\text { Over } \\
5000\end{array}$ & Proportion & $\begin{array}{l}\text { Proportional } \\
\text { Difference }\end{array}$ & Confidence Interval (95\%) \\
\hline Self & 114 & 0.259091 & 60 & 0.196078 & -0.06301 & 0.0604562 \\
\hline Agent & 28 & 0.063636 & 14 & 0.045752 & -0.01788 & inside \\
\hline Paralegal & $\mathbf{3 7}$ & $\mathbf{0 . 0 8 4 0 9 1}$ & $\mathbf{6 0}$ & $\mathbf{0 . 1 9 6 0 7 8}$ & $\mathbf{0 . 1 1 1 9 8 8}$ & $\mathbf{0 . 0 5 1 4 9 1 9}$ \\
\hline Lawyer & $\mathbf{4 9}$ & $\mathbf{0 . 1 1 1 3 6 4}$ & $\mathbf{8 5}$ & $\mathbf{0 . 2 7 7 7 7 8}$ & $\mathbf{0 . 1 6 6 4 1 4}$ & $\mathbf{0 . 0 5 8 1 6 0 3}$ \\
\hline $\begin{array}{l}\text { Collection } \\
\text { Agency }\end{array}$ & 48 & 0.109091 & 19 & 0.062092 & -0.047 & 0.0397451 \\
\hline Employee & $\mathbf{1 6 4}$ & $\mathbf{0 . 3 7 2 7 2 7}$ & $\mathbf{6 8}$ & $\mathbf{0 . 2 2 2 2 2}$ & $\mathbf{- 0 . 1 5 0 5 1}$ & $\mathbf{0 . 0 6 4 8 9 3 5}$ \\
\hline Total & 440 & 1 & 306 & 1 & & \\
\hline
\end{tabular}

Table $14-2011$ Plaintiff Representation by Claim Value ${ }^{153}$

\begin{tabular}{|l|l|l|l|l|l|l|l|}
\hline 2011 & $<12,500$ & Proportion & $>12,500$ & Proportion & $\begin{array}{l}\text { Proportion } \\
\text { difference }\end{array}$ & $\begin{array}{l}\text { Confidence } \\
\text { Interval (95\%) }\end{array}$ & $\begin{array}{l}\text { Confidence } \\
\text { Interval (90\%) }\end{array}$ \\
\hline Self & 133 & 0.238779 & 55 & 0.264423 & 0.025644 & 0.069482 & 0.058315 \\
\hline Agent & 20 & 0.035907 & 5 & 0.024038 & -0.01187 & inside & inside \\
\hline Paralegal & 108 & 0.193896 & 38 & 0.182692 & -0.0112 & 0.061933 & 0.051980 \\
\hline Lawyer & $\mathbf{1 2 6}$ & $\mathbf{0 . 2 2 6 2 1 2}$ & $\mathbf{8 0}$ & $\mathbf{0 . 3 8 4 6 1 5}$ & $\mathbf{0 . 1 5 8 4 0 4}$ & $\mathbf{0 . 0 7 4 6 9}$ & $\mathbf{0 . 0 6 2 6 8 7}$ \\
\hline Collection & 32 & 0.057451 & 5 & 0.024038 & -0.03341 & .0354214 & 0.029555 \\
\hline Employee & $\mathbf{1 3 8}$ & $\mathbf{0 . 2 4 7 7 5 6}$ & $\mathbf{2 5}$ & $\mathbf{0 . 1 2 0 1 9 2}$ & $\mathbf{- 0 . 1 2 7 5 6}$ & $\mathbf{0 . 0 5 6 9 0 7}$ & $\mathbf{0 . 0 4 7 7 6 2}$ \\
\hline Total & 557 & 1 & 208 & 1 & & & \\
\hline
\end{tabular}

151 With such small sample sizes there are no statistically significant differences in representation proportions for plaintiffs in collection files between 2008 and 2011 as the proportional differences are well inside the confidence intervals at $95 \%$ and even $90 \%$ levels. Confidence intervals at $90 \%$ are plus or minus dependent: .07898 independent: .07831 employee: .09677; (zero remains in the intervals).

152 Chi-squared test results for data in Table 13 score 152.752 , well over 11.07 critical value for $95 \%$ statistical significant with 5 degrees of freedom; P-value of less than .0001.

153 Chi-squared test results 42.298 is greater than 11.07 needed for $95 \%$ confidence at 5 degrees of freedom. 
Table 15 - Plaintiff Representation on Claims of \$5,000 or Less

\begin{tabular}{|l|l|l|l|l|l|l|}
\hline Type & $\begin{array}{l}2008 \$ 5,000 \\
\text { or less }\end{array}$ & $\begin{array}{l}2008 \\
\text { Proportion }\end{array}$ & $\begin{array}{l}2011 \\
\$ 5,000 \text { or } \\
\text { less }\end{array}$ & $\begin{array}{l}2011 \\
\text { Proportion }\end{array}$ & $\begin{array}{l}\text { Proportional } \\
\text { Difference }\end{array}$ & $\begin{array}{l}\text { Confidence Interval } \\
(95 \%)\end{array}$ \\
\hline Self & 114 & 0.259091 & 94 & 0.29375 & 0.034659 & 0.064549 \\
\hline Agent & 28 & 0.063636 & 12 & 0.0375 & -0.02614 & inside \\
\hline Paralegal & $\mathbf{3 7}$ & $\mathbf{0 . 0 8 4 0 9 1}$ & $\mathbf{5 1}$ & $\mathbf{0 . 1 5 9 3 7 5}$ & $\mathbf{0 . 0 7 5 2 8 4}$ & $\mathbf{0 . 0 4 7 7 5 8}$ \\
\hline Lawyer & 49 & 0.111364 & 41 & 0.128125 & 0.016761 & 0.046958 \\
\hline Collection A & $\mathbf{4 8}$ & $\mathbf{0 . 1 0 9 0 9 1}$ & $\mathbf{1 8}$ & $\mathbf{0 . 0 5 6 2 5}$ & $\mathbf{- 0 . 0 5 2 8 4}$ & $\mathbf{0 . 0 3 9 0 0 5}$ \\
\hline Employee & 164 & 0.372727 & 104 & 0.325 & -0.04773 & 0.068373 \\
\hline Total & 440 & 1 & 320 & 1 & & \\
\hline
\end{tabular}

Table 16 - Plaintiffs Adjudicative Claims \$5,000 or Less Clustered Categories

\begin{tabular}{|l|l|l|l|l|l|l|l|}
\hline Type & $\begin{array}{l}2008 \\
\$ 5,000 \\
\text { or less }\end{array}$ & $\begin{array}{l}2008 \\
\text { Proportion }\end{array}$ & $\begin{array}{l}2011 \\
\$ 5,000 \\
\text { or less }\end{array}$ & $\begin{array}{l}2011 \\
\text { Proportion }\end{array}$ & $\begin{array}{l}\text { Proportional } \\
\text { Difference }\end{array}$ & $\begin{array}{l}\text { Confidence } \\
\text { Interval } \\
(95 \%)\end{array}$ & $\begin{array}{l}\text { Confidence } \\
\text { Interval }(90 \%)\end{array}$ \\
\hline Dependent & 114 & 0.259091 & 94 & 0.29375 & 0.034659 & 0.064549 & 0.054175 \\
\hline Independent & 162 & 0.368182 & 122 & 0.38125 & 0.013068 & 0.069735 & 0.058528 \\
\hline Employee & $\mathbf{1 6 4}$ & $\mathbf{0 . 3 7 2 7 2 7}$ & $\mathbf{1 0 4}$ & $\mathbf{0 . 3 2 5}$ & $\mathbf{- 0 . 0 4 7 7 3}$ & $\mathbf{0 . 0 4 6 5 1 8}$ & $\mathbf{0 . 0 3 9 0 4 2}$ \\
\hline Total & 440 & 1 & 320 & 1 & & & \\
\hline
\end{tabular}

Table 17 - Plaintiff Representation on Claims \$5,001 to \$10,000 for 2008 and 2011

\begin{tabular}{|l|l|l|l|l|l|l|}
\hline Type & $\begin{array}{l}2008 \\
\$ 5,001 \text { to } \\
10,000\end{array}$ & $\begin{array}{l}2008 \\
\text { Proportion }\end{array}$ & $\begin{array}{l}2011 \\
\$ 5,001 \text { to } \\
\$ 10,000\end{array}$ & $\begin{array}{l}2011 \\
\text { Proportion }\end{array}$ & $\begin{array}{l}\text { Proportional } \\
\text { difference }\end{array}$ & $\begin{array}{l}\text { Confidence Interval } \\
(95 \%)\end{array}$ \\
\hline Self & 60 & 0.196078 & 32 & 0.171123 & -0.024955 & 0.069962 \\
\hline Agent & 14 & 0.045752 & 7 & 0.037433 & -0.008319 & inside \\
\hline Paralegal & 60 & 0.196078 & 45 & 0.240642 & 0.0445637 & 0.075716 \\
\hline Lawyer & 85 & 0.277778 & 62 & 0.331551 & 0.0537728 & 0.084092 \\
\hline $\begin{array}{l}\text { Collection } \\
\text { Agency }\end{array}$ & 19 & 0.062092 & 13 & 0.069519 & 0.0074267 & 0.045387 \\
\hline Employee & $\mathbf{6 8}$ & $\mathbf{0 . 2 2 2 2 2 2}$ & $\mathbf{2 8}$ & $\mathbf{0 . 1 4 9 7 3 3}$ & $\mathbf{- 0 . 0 7 2 4 8 9 3}$ & $\mathbf{0 . 0 6 9 1 7 6}$ \\
\hline Total & 306 & 1 & 187 & 1 & & \\
\hline
\end{tabular}


Table 18 - Plaintiff Representation $\$ 5,001$ to $\$ 10,000$ Clustered Categories

\begin{tabular}{|l|l|l|l|l|l|l|}
\hline \multicolumn{1}{|c|}{ Type } & $\begin{array}{l}2008 \$ 5,001 \text { to } \\
10,000\end{array}$ & $\begin{array}{l}2008 \\
\text { Proportion }\end{array}$ & $\begin{array}{l}2011 \\
\$ 5,001 \text { to } \\
10,000\end{array}$ & $\begin{array}{l}2011 \\
\text { Proportion }\end{array}$ & $\begin{array}{l}\text { Proportional } \\
\text { difference }\end{array}$ & $\begin{array}{l}\text { Confidence } \\
\text { Interval }(95 \%)\end{array}$ \\
\hline Dependent & 60 & 0.196078 & 32 & 0.171123 & -0.024955 & 0.069962 \\
\hline Independent & $\mathbf{1 7 8}$ & $\mathbf{0 . 5 8 1 7 0 0}$ & $\mathbf{1 2 7}$ & $\mathbf{0 . 6 7 9 1 4 4}$ & $\mathbf{. 0 9 7 4 4 4}$ & $\mathbf{0 . 0 8 6 7 8 3}$ \\
\hline Employee & $\mathbf{6 8}$ & $\mathbf{0 . 2 2 2 2 2 2}$ & $\mathbf{2 8}$ & $\mathbf{0 . 1 4 9 7 3 3}$ & $\mathbf{- 0 . 0 7 2 4 8 9}$ & $\mathbf{0 . 0 6 9 1 7 6}$ \\
\hline Total & 306 & 1 & 187 & 1 & & \\
\hline
\end{tabular}

Table 19 - Defendant Representation (at issue) in Adjudication Files

\begin{tabular}{|l|l|l|l|l|l|l|l|}
\hline Type & 2008 & $\begin{array}{l}2008 \\
\text { Proportion }\end{array}$ & 2011 & $\begin{array}{l}2011 \\
\text { Proportion }\end{array}$ & $\begin{array}{l}\text { Year over } \\
\text { Year \% } \\
\text { change }\end{array}$ & $\begin{array}{l}\text { Proportional } \\
\text { Difference }\end{array}$ & $\begin{array}{l}\text { Confidence Interval } \\
(95 \%)\end{array}$ \\
\hline Self & 110 & 0.404411 & 98 & .3333333 & $-19.09 \%$ & -.07108 & 0.079407 \\
\hline Agent & 7 & 0.025735 & 11 & 0.037415 & $49.06 \%$ & .01168 & 0.063338 \\
\hline Paralegal & 14 & 0.051471 & 21 & 0.071429 & $41.91 \%$ & .019958 & 0.039449 \\
\hline Lawyer & 86 & 0.316176 & 107 & 0.363945 & $16.33 \%$ & .047769 & 0.077964 \\
\hline Collection A & 1 & 0.003676 & 0 & 0 & $-108.07 \%$ & -.003676 & too small \\
\hline Employee & 51 & 0.1875 & 54 & 0.183673 & $-2.296 \%$ & .003827 & inside \\
\hline Other & 3 & 0.011029 & 3 & 0.010204 & irrelevant & irrelevant & irrelevant \\
\hline Total & 272 & 1 & 294 & 1 & & & \\
\hline
\end{tabular}

Table 20 - Defendant Clustered Category Representation Before and After

\begin{tabular}{|l|l|l|l|l|l|l|l|l|}
\hline Type & 2008 & $\begin{array}{l}2008 \\
\text { Proportion }\end{array}$ & 2011 & $\begin{array}{l}2011 \\
\text { Proportion }\end{array}$ & $\begin{array}{l}\text { Year } \\
\text { Over } \\
\text { Year\% } \\
\text { Change }\end{array}$ & $\begin{array}{l}\text { Proportional } \\
\text { Difference }\end{array}$ & $\begin{array}{l}\text { Confidence } \\
\text { Interval } \\
(95 \%)\end{array}$ & $\begin{array}{l}\text { Confidence } \\
\text { Interval } \\
(90 \%)\end{array}$ \\
\hline Dependent & 110 & 0.408922 & 98 & 0.33677 & $-19.09 \%$ & -0.07215 & 0.080003 & $\mathbf{0 . 0 6 7 1 4 5}$ \\
\hline Independent & 108 & 0.401487 & 139 & 0.477663 & $20.53 \%$ & 0.07618 & 0.082009 & $\mathbf{0 . 0 6 8 8 2 9}$ \\
\hline Employee & 51 & 0.189591 & 54 & 0.185567 & $-2.30 \%$ & -0.00402 & inside & inside \\
\hline Total & 269 & 1 & 291 & 1 & & & & \\
\hline
\end{tabular}

Table 21 - 2008 Defendant 2008 Representation by Claim Value

\begin{tabular}{|l|l|l|l|l|l|l|}
\hline 2008 & $\begin{array}{l}5000 \text { or } \\
\text { Less }\end{array}$ & Proportion & $\begin{array}{l}\text { Over } \\
5000\end{array}$ & Proportion & $\begin{array}{l}\text { Proportional } \\
\text { Difference }\end{array}$ & Confidence Interval (95\%) \\
\hline Dependent & $\mathbf{7 0}$ & $\mathbf{. 5 6}$ & $\mathbf{4 0}$ & $\mathbf{. 2 7 9 7 2}$ & $\mathbf{- 0 . 2 8 0 2 8}$ & $\mathbf{0 . 1 1 3 9 6 8}$ \\
\hline
\end{tabular}

1542008 expected frequency levels were adjusted for 2011 sample size. 


\begin{tabular}{|l|l|l|l|l|l|l|}
\hline Independent $^{155}$ & $\mathbf{3 9}$ & $\mathbf{. 3 1 2}$ & $\mathbf{6 8}$ & $\mathbf{. 4 7 5 5 3}$ & $\mathbf{0 . 1 6 3 5 2 4}$ & $\mathbf{0 . 1 1 5 3 1 3}$ \\
\hline Employee & $\mathbf{1 6}$ & $\mathbf{. 1 2 8}$ & $\mathbf{3 5}$ & $\mathbf{. 2 4 4 7 6}$ & $\mathbf{0 . 1 1 6 7 5 5}$ & $\mathbf{0 . 0 9 1 6 3 1}$ \\
\hline Total $^{156}$ & 125 & 1 & 143 & 1 & & \\
\hline
\end{tabular}

Table 22 - Defendant 2011 Representation by Claim Value

\begin{tabular}{|l|l|l|l|l|l|l|}
\hline 2008 & $\begin{array}{l}12500 \text { or } \\
\text { Less }\end{array}$ & Proportion & $\begin{array}{l}\text { Over } \\
12500\end{array}$ & Proportion & $\begin{array}{l}\text { Proportion } \\
\text { difference }\end{array}$ & $\begin{array}{l}\text { Confidence Interval } \\
(95 \%)\end{array}$ \\
\hline Dependent & $\mathbf{7 7}$ & $\mathbf{0 . 4 2 5 4 1 4}$ & $\mathbf{2 1}$ & $\mathbf{0 . 1 9 0 9 0 9}$ & $\mathbf{- 0 . 2 3 4 5 1}$ & $\mathbf{0 . 1 0 2 8 6 1}$ \\
\hline Independent $^{157}$ & $\mathbf{7 0}$ & $\mathbf{0 . 3 8 6 7 4}$ & $\mathbf{6 9}$ & $\mathbf{0 . 6 2 7 2 7 3}$ & $\mathbf{0 . 2 4 0 5 3 2}$ & $\mathbf{0 . 1 1 4 8 8 7}$ \\
\hline Employee & 34 & 0.187845 & 20 & 0.181818 & -0.00603 & inside \\
\hline Total & 181 & 1 & 110 & 1 & & \\
\hline
\end{tabular}

Table 23 - Defendant Representation on Claims of $\$ 5,000$ or Less

\begin{tabular}{|l|l|l|l|l|l|l|l|}
\hline Type & $\begin{array}{l}2008 \\
\$ 5,000 \\
\text { or less }\end{array}$ & $\begin{array}{l}2008 \\
\text { Proportion }\end{array}$ & $\begin{array}{l}2011 \\
\$ 5,000 \\
\text { or less }\end{array}$ & $\begin{array}{l}2011 \\
\text { Proportion }\end{array}$ & $\begin{array}{l}\text { Proportional } \\
\text { Difference }\end{array}$ & $\begin{array}{l}\text { Confidence } \\
\text { Interval } \\
(95 \%)\end{array}$ & $\begin{array}{l}\text { Confidence } \\
\text { Interval }(90 \%)\end{array}$ \\
\hline Dependent & 70 & .56 & 47 & 0.49474 & -0.06526 & 0.13298 & 0.111611 \\
\hline Independent & 39 & .312 & $32^{158}$ & 0.33684 & 0.02484 & 0.132997 & 0.111623 \\
\hline Employee & 16 & .128 & 16 & 0.16842 & 0.04042 & 0.095362 & 0.080035 \\
\hline Total & 125 & 1 & 95 & 1 & & & \\
\hline
\end{tabular}

Table 24 - Defendant Representation on Claims $\$ 5,001$ to $\$ 10,000$

\begin{tabular}{|c|c|c|c|c|c|c|c|}
\hline Type & $\begin{array}{l}2008 \\
\$ 5,001 \text { to } \\
\$ 10,000\end{array}$ & $\begin{array}{l}2008 \\
\text { Proportion }\end{array}$ & $\begin{array}{l}2011 \\
\$ 5,001 \quad \text { to } \\
\$ 10,000\end{array}$ & $\begin{array}{l}2011 \\
\text { Proportion }\end{array}$ & $\begin{array}{l}\text { Proportional } \\
\text { Difference }\end{array}$ & $\begin{array}{l}\text { Confidence } \\
\text { Interval } \\
(95 \%)\end{array}$ & $\begin{array}{l}\text { Confidence } \\
\text { Interval }(90 \%)\end{array}$ \\
\hline Dependent & 40 & .27972 & 23 & 0.34328 & 0.06356 & 0.13542 & 0.11366 \\
\hline Independent & 68 & .47553 & $31^{159}$ & 0.46269 & -0.01284 & 0.14018 & 0.11765 \\
\hline Employee & 35 & .24476 & 13 & 0.19403 & -0.05073 & 0.11804 & 0.09907 \\
\hline Total & 143 & 1 & 67 & 1 & & & \\
\hline
\end{tabular}

Definitions - Types of Representation

\begin{tabular}{|l|l|}
\hline Self & $\begin{array}{l}\text { Litigant represents him or herself or uses a friend or family member (only in Table } 7 \text { are friend and family } \\
\text { considered separate from self) }\end{array}$ \\
\hline
\end{tabular}

155 Lawyers were 28 of the 39 under $\$ 5,000$ and 54 of the 68 in over 5,000 .

156 The 272 sample size had one file with a missing value so it dropped to 271 in this value analysis; of the 3 files in the "other" category 1 were above 5000 and 2 were below.

157 Lawyers make up 46 of the Independent category for claims under 12,500 and 56 of claims over 12,500.

158 Lawyers make up 21 of this Independent total, paralegals make up 5.

159 Lawyers make up 20, paralegals make up 7. 


\begin{tabular}{|l|l|}
\hline Agent & Arms-length representative of undisclosed status \\
\hline Paralegal & Licensed and unlicensed Paralegals \\
\hline Lawyer & $\begin{array}{l}\text { Lawyer and Articling Students (students at law) employed by law firms (Only in Table 7 are the two listed } \\
\text { separately) }\end{array}$ \\
\hline Collection & Collection Agency employees where Collection Agency is not a party \\
\hline Employee & An employee of party entity \\
\hline Dependent & $\begin{array}{l}\text { Clustered category of self-representatives and non-arms-length unpaid representatives such as family and } \\
\text { friends }\end{array}$ \\
\hline Independent & Clustered categories of Agent, Collection Agency, Paralegal and Lawyers \\
\hline
\end{tabular}

